\title{
IMAGE OF CITIES AS TOOL FOR URBAN GOVERNANCE IN MERCOSUR: CONTRIBUTIONS FROM URBAN AND CITY BRANDING ${ }^{1}$
}

\author{
Donizete Ferreira Beck \\ Nove de Julho University - UNINOVE \\ São Paulo, SP - Brazil. \\ donizetebeck@uni9.edu.br \\ Marcos Ferasso \\ Universidade Autónoma de Lisboa - UAL. \\ Lisbon, Lisbon - Portugal. \\ admmarcosferasso@gmail.com
}

Purpose: This research aims to analyze the knowledge structure related to the image of the cities as a tool for urban governance in Mercosur context.

Method: A research synthesis was applied to analyze and discuss (1) theoretical contributions, (2) urban image ontology and deontology, and (3) the challenges of urban image as a tool for urban governance in Mercosur context.

Originality / Relevance: We synthesized the theoretical contributions, the understanding of urban image ontology and deontology, and the urban image challenges in urban branding and city branding as a tool for urban governance in Mercosur context.

Results: Findings on urban image in Mercosur context reveal that: (1) regional research is aligned with seminal one, stating that socioeconomic inclusion, sustainability, smartness, stakeholder convergence and satisfaction, and city attractiveness are essential parts of urban image as an urban governance tool for sustainable urban development; (2) urban image has been considered a tool for promoting the urban development, management, and governance, which has varied understandings for diverse urban stakeholders; and (3) the main regional challenges.

Theoretical / Methodological Contributions: We endorse seminal research arguments on the role of urban image in urban governance through research synthesis on urban image in Mercosur context, considering regional challenges and perspectives.

Social / Managerial Contributions: Regional and local communities have their needs met, and bottom-up approach, sustainable development, and democracy are encouraged in urban governance.

Keywords: City. Urban. Branding. Image. Mercosur. Development. Governance.

\section{How to cite the article}

American Psychological Association (APA)

Beck, D. F., \& Ferasso, M. (2022, Jan./Mar.). Image of cities as tool for urban governance in Mercosur: contributions from urban and city branding. Brazilian Journal of Marketing, 21(Special Issues), 9-28. https://doi.org/10.5585/remark.v21i1.19354.

1"This research was partially financed supported by the Council for Higher Education of Israel (CHE, המועצה להשכלה גבוהה, Israel) and partially financed by the Brazilian agency for research funding called 'Coordenação de Aperfeiçoamento de Pessoal de Nível Superior' (CAPES, Brazil)." 


\section{Introduction}

The world has become even more urbanized, more people are living within cities, and cities are becoming part of the sense of belonging of the people (Pedeliento \& Kavaratzis, 2019; Zenker, Braun, \& Petersen, 2017; Kotler, Haider e Rein, 1993). Then, the image and brand of the cities constitute not only a mere image of a place, but also a reflection of the common values, culture, behavior, way of thinking, and even it reflects the personality of the city dwellers (Evans, 2015; Kerr \& Oliver, 2015; Kotler et al., 1993; among others). One reason for this phenomenon is that cities have more conditions to provide better quality of life for people than rural areas, and people have simultaneously developed some feelings in relation to their places (Kerr \& Oliver, 2015; Morgan \& Pritchard, 2001).

More importantly, psychological perceptions on the urban branding and image from all kinds of people, as residents, tourists, and industries are one of the pillars which explains the success or failure of urban development (Avraham \& Ketter, 2008; Kotler et al., 1993). In this way, a positive city image could have a magnetic function to attract desirable urban development, urban stakeholders, people, investments, and businesses, such that the dynamism of the cities will be higher and prosperous (Avraham \& Ketter, 2008; Cañizares, Tabales, \& Garcia, 2014; Kotler et al., 1993; Oliveira, 2015; Beck \& Storopoli, 2021). Thus, urban image could be a tool for urban governance (Lucarelli \& Berg, 2011).

In the Southern Hemisphere, the Mercosur (i.e. the common market of the south) is an intergovernmental organization which is a free trade bloc, and in the future has the potential to become a supranational union. The importance to study the urban branding and image within the context of the countries of the Mercosur is that those countries - Argentina, Brazil, Paraguay, Uruguay, and Venezuela - are developing countries, and working on the place branding, as the urban one, could be helpful to cities of those countries which aim to overcome their challenges, leading them to have a better urban development, higher employment rates, and also a better pattern of life and conditions to their city dwellers.

In Brazil, a Mercosur country, many studies have shown the critical role of country image in its reputation, development, and identity (Mariutti \& Tench, 2016; Mariutti, 2017; Mariutti \& Giraldi, 2019; Mariutti \& Giraldi, 2020), but little is know on the role of the image of cities in Brazil and other Mercosur countries. Therefore, the purpose of this study is to analyze the knowledge structure related to the image of the cities as a tool for urban governance within the Mercosur context. 
We performed a Research Synthesis (Cooper, 2017), considering three specific goals related to the urban image as a tool for urban governance within the Mercosur context: (1) theoretical contributions, (2) urban image ontological and deontological understandings, and (3) regional challenges. Our purpose is limited only to the urban image within the Mercosur context, nonetheless the state of art on city branding has already been widely explored by scholars, such as Hanna, Rowley, and Keegan (2021), Górska-Warsewicz (2020), Oguztimur and Akturan (2016), Green, Grace, and Perkins (2016), and Lucarelli and Berg (2011).

Although little is known and there are no many publications on urban branding within the context of the countries of Mercosur, our results stemmed from an analysis of 10 publications providing a rich framework, which public managers and all the urban stakeholders of urban governance systems should consider it in order to improve urban image, foster urban socioeconomic development, and political structure (Pierre, 2011; Cañizares et al., 2014; Oliveira, 2015; Lucarelli \& Giovanardi, 2016; Beck \& Storopoli, 2021). In effect, the success of the cities is also the self one of their business, residents, and urban stakeholders. Therefore, urban image matters.

The following topic explains what urban branding and image are, as well as, it explores what the literature has been published on it. Then, we detailed the method adopted in this research. After that, we present our results and discuss them with the literature, and so we conclude synthesizing our main findings, research limitations, and proposing some suggestions of future studies.

\section{Urban image in urban branding}

Urban branding is the promotion of cities in order to attract more investments, industries, tourists, and city dwellers, and then, promoting a desired urban development and taking healthy advantage among other cities. According to the seminal Kotler, Haider and Rein (1993), cities could better exploit their branding to overcome some socio economic issues, that is, urban branding could be used to promote urban development and prevent cities from decaying of their dynamism. In doing so, cities could become more attractive and avoid outward migration of people, business, tourism, conventions, and industries, as well as deploying a strategy to not raise governmental taxes. Also, cities are objects of consumption, in which people and businesses compare each one of them and try to find which one is the better choice to live or invest (Avraham \& Ketter, 2008). 
Avraham and Ketter (2008) highlighted that urban branding is, generally, used to tourism management in order that a city leads on a certain tourism niche, in which some branding concepts from marketing are used, such as those related to design, values, identity, and image strategy. So, the place positioning is a central concern of scholars and practitioners on place branding, in this case applying it to the cities. According to Hankison (2015), the core of place branding is based on six axes: brand image (e.g. Pedeliento \& Kavaratzis, 2019; Mariutti \& Giraldi, 2020), brand positioning and equity (e.g. Florek \& Kavaratzis, 2014; Mariutti \& Giraldi, 2020; Górska-Warsewicz, 2020), brand extension, brand architecture, brand identity (e.g. Skinner, 2008; Florek, Insch, \& Gnoth, 2006; Zenker, Braun, \& Petersen, 2017; Pedeliento \& Kavaratzis, 2019), and brand orientation. Although this paper does not aim to perform a quantitative study, it was important to mention those constructs to better situate our reader. In this study, we work only on the brand image axe.

In turn, city branding is, according to Lucarelli and Berg (2011, p. 22), an "internationally recognized research domain characterized by a high degree of multidisciplinarity, a rapid proliferation in and between disciplines, and a somewhat fragmented theoretical foundation". It is also considered a tool for urban governance, connecting the urban image perceived by residents to governmental communication (Zucco et al., 2017). The difference between urban branding and city branding is that the first one is a theoretical approach to foster urban sustainability, while the second one is an urban communication aspect that can improve the urban image (Rehan, 2014).

Considering the urban image, Kotler et al. (1993, p. 35) pointed out that it depends on the "current image and real attributes" of the cities which could be positive, weak, negative, mixed, contradictory, and overly attractive. Urban image is "the sum of beliefs, ideas, and impressions that a people have" of a city (Kotler et al., 1993, p. 141). These "images aren't easy to develop or change. They require research into how residents and outsiders currently see the place; (...) identifying true and untrue elements, (...) strong and weak elements; (...) consensual image (...)" (Kotler et al., 1993, p. 37).

The bottom-line is that urban branding and city branding have been useful tools for urban managers and urban stakeholders in urban governance, in which the image of cities play a critical role in urban attractiveness, stakeholder satisfaction (e.g. citizens, business, and industries), and decision-making of urban stakeholders and urban managers (Lucarelli \& Berg, 2011; Rehan, 2014; Zucco et al., 2017; Beck \& Storopoli, 2021). 
There are three levels of place marketing, from wider to narrower: (1) target markets; (2) marketing factors; and (3) group of urban planners. Kotler et al. (1993) state that when cities are selecting their target markets, the context in which they are located should be taken into account, and then, making the urban branding to those targets should be done. In this way, some examples of targets are: tourists and conventioneers; exporters; investors; manufacturers; corporate headquarters; and new residents. Even more, cities should consider the marketing factors that affect the quality of the urban branding, such as the urban infrastructure, peoplerelated issues (e.g. culture), urban attractions and events, and also the image and urban quality of life.

In this way, urban planners identify a diagnostic, plan a vision, and implement required actions to promote the urban image through the relationship among citizens, governments, and industries. Thus, cities could exploit their image, attractions, infrastructure and people to attract their target markets, improve urban governance, and satisfy a wider range of urban stakeholders (Kotler et al., 1993; Avraham \& Ketter, 2008; Rehan, 2014; Zucco et al., 2017; Beck \& Storopoli, 2021).

Therefore, the urban image drives the decision-making process of people, business and tourists in relation to their urban activities and in urban governance. Then, an efficient urban governance exploits the mass media and campaigns techniques in order to maintain or change an urban image to be successful, and then the urban reality (Avraham \& Ketter, 2008; Zucco et al., 2017). Figure 1 illustrates a synthesis on how the brand image on urban branding can affect urban development. 


\section{Figure 1}

A Synthesis of the Urban Image Importance in Urban Branding for Urban Development.

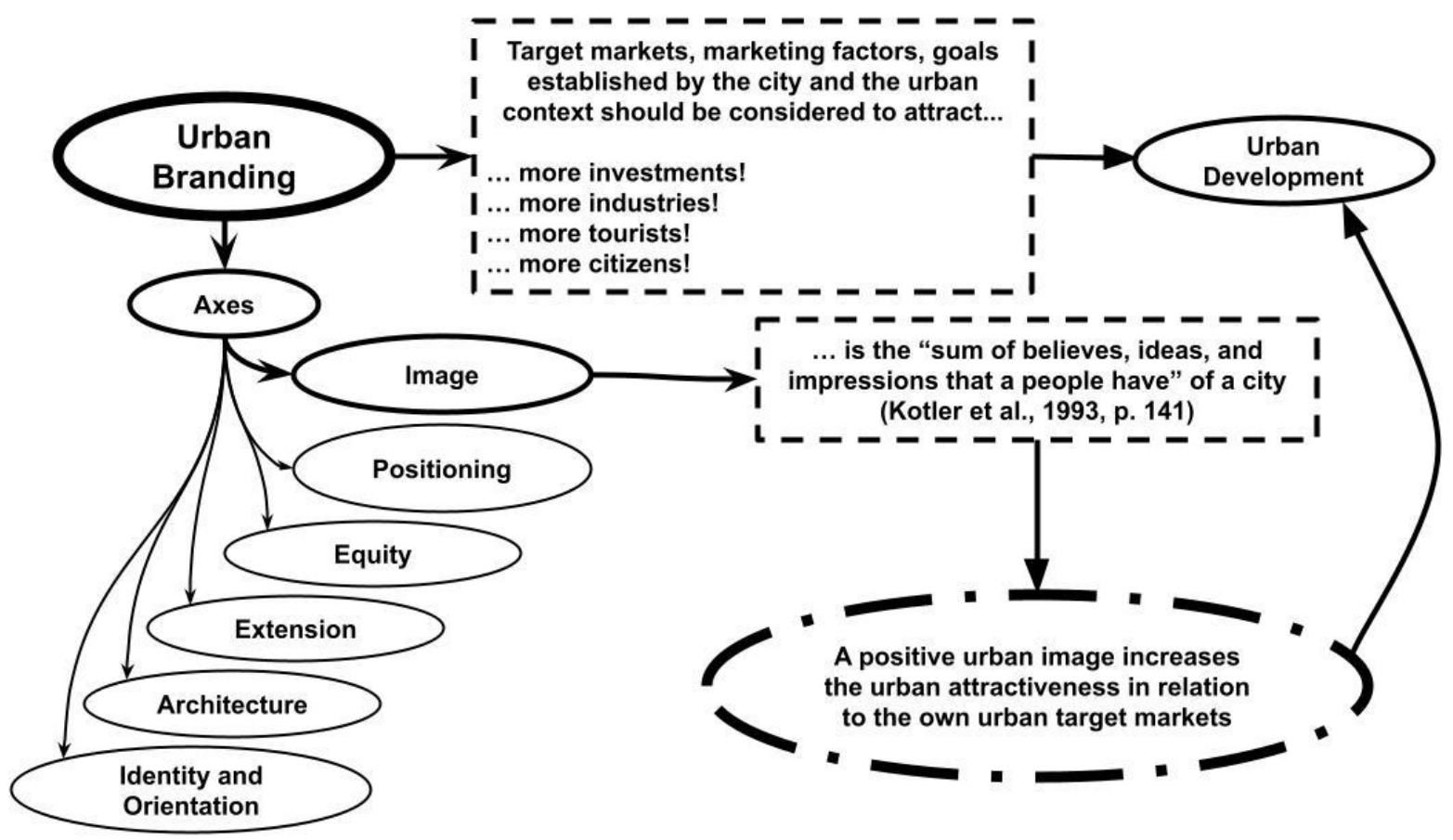

Source: Own elaboration.

Some scholars have written on the future trends of place marketing, those ones lie at the emergence of the Informational and Communicational Technologies (ICTs), the digitalization of daily lives, and also on the changing pattern of strategic communication. For instance, the place branding is a process which longs all the time and is unstoppable within the context of digital social media (Fous, 2010); e-branding and its implementation in cities (Gover \& Go, 2010); the innovation process of place branding (Halemane Janszen \& Go, 2010); place identities in place branding (Kerr \& Oliver, 2015); the own construct of place branding (Hankinson, 2015); sense of place among individuals (Campelo, 2015); the role of virtual and online place branding as well as their digital strategies (Hanna \& Rowley, 2015; Govers, 2015); culture and creativity (Evans, 2015). Among others themes and approaches related to what already has been demonstrated in this paragraph since the seminal publication of Kotler (1993) on urban branding and marketing places.

Nowadays, the group of Mihalis Kavaratzis and Gregory Ashworth are one of the most influential groups of scholars on the topic of urban and place branding due to the high-impact of their publications as well as to their critical theoretical and practical contributions. They have been worked on, since the beginning of the 21 st Century until today on: the nature of the city 
branding, analyzing if it has an effective assertion of the identity of the people or a positivistic and transitory trick of managers (Kavaratzis \& Ashworth, 2005); reviewing trends, measures, and conceptual models of place branding, origin branding, cultural branding, entertainment branding, destination branding, and even corporate branding (Kavaratzis, 2005); also, the role of a primary communication focused on the behavior of the city at developing landscape strategies, infrastructure projects, and organizational structure (Kavaratzis, 2005); on the secondary communication at developing a communication with main goals to be accomplished differently of the primary one (Kavaratzis, 2005); the importance of the logo in urban branding (Ashworth \& Kavaratzis, 2009); the dynamism of place brands and identities, in which are not static and requires a permanent dialogue in order to promote consensus on place branding (Kavaratzis \& Hatch, 2013); on the importance of the engagement of the residents and feelings of belonging to the place (Braun, Kavaratzis \& Zenker, 2013); among others relevant studies.

\section{Method}

In order to accomplish the research purpose, we performed a research synthesis (RS) gathering data from the Scopus database, which is considered the most comprehensive scholarly database in social sciences. Research syntheses use rigorous and transparent ways of conducting literature reviews to synthesize several and cumulative findings of a research specific topic (Cooper, 2017). In a nutshell, research syntheses have seven steps (Cooper, 2017): (1) formulating the problem; (2) searching the literature; (3) gathering data and information from studies; (4) evaluating the quality of studies; (5) analyzing and integrating the outcomes of studies; (6) interpreting the evidences; and (7) presenting the results. In this study, the research specific topic is related to urban image in urban branding as a tool for urban governance within the Mercosur context.

Our search expression considered any possibilities of terms related to urban branding, urban marketing, and place marketing in all the countries of the Mercosur (i.e. Argentina, Brazil, Paraguay, Uruguay, and Venezuela). Also, we considered any kind of publication published before 2020. For the purpose of replication (Aguinis, Ramani \& Alabduljader, 2017), our first search expression is: TITLE-ABS-KEY ( "urban brand*" OR "urban mark*" OR "market* place\$" AND "Argentina" OR "Brazil" OR "Paraguay" OR "Uruguay" OR "Venezuela" ) AND PUBYEAR < 2020. And then, 55 documents resulted from this search expression. When reading the abstract of those documents, we removed 47 documents, which are not related to urban image, urban branding, or to the countries of Mercosur, thus we 
excluded them from our sample. So, our final sample contains only 8 documents which remained from the cleaning process.

After that, we conducted a second search in Scopus for identifying the terms: TITLEABS-KEY ("city brand*" AND "Argentina" OR "Brazil" OR "Paraguay" OR "Uruguay" OR "Venezuela") AND PUBYEAR < 2020. Three documents were obtained from this search expression, but only two new papers were included in the analysis (Zucco et al., 2017; Maielle \& Pasquinelli, 2015), and one paper was already included in the first search (Dinardi, 2017).

According to Cooper (2017), there are often more than two specific goals in research syntheses. In this study, there are three specific goals related to urban image in urban branding and city branding as a tool for urban governance within the Mercosur context, of which were considered in the results and discussion section: first, the theoretical contributions, core ideas and findings of those documents; second, the distinction between the urban image ontology and deontology in the region; and third, the regional related-challenges.

\section{Results and discussion}

Table 1 shows us the list of the ten publications selected in our RS. Five of those ten publications lead with the reality of Argentina (Carré \& Fernández, 2013; Dinardi, 2017; Lederman, 2015; Ñunez \& Barelli, 2013; Roldán, 2013), four studies are on the Brazilian reality (Scholvin \& Westhuizen, 2019; Yigitcanlar et al., 2018; Zucco et al., 2017; Maielle \& Pasquinelli, 2015), and one is related to the context of Venezuela (Arroyo \& Montero, 2000). Our sample does not contain studies on the urban image and branding from Paraguay or Uruguay. 
Table 1

Relation of the Documents Which Are Part of the Sample of this Research Synthesis

\begin{tabular}{ccc}
\hline $\begin{array}{c}\text { Author(s) } / \\
\text { Year }\end{array}$ & Name & $\begin{array}{c}\text { Theoretical contribution(s) to Urban Image in } \\
\text { Urban/City Branding }\end{array}$ \\
\hline
\end{tabular}

Scholvin and

1 Van der Cape Town and Rio de Janeiro:

Westhuizen $\begin{aligned} & \text { Attractive world cities and their dark } \\ & \text { sides }\end{aligned}$

(2019)

Yigitcanlar Towards smart Florianópolis: What et al. (2018) does it take to transform a tourist island into an innovation capital?

3 Dinardi (2017)

4

Zucco et al. brand from the residents' perspective, (2017) and its influence on the decision to stay in the destination

Maiello and Destruction or construction? A

5 Pasquinelli (counter) branding analysis of sport (2015)

$\begin{array}{ll}\text { Lederman } & \text { Urban fads and consensual fictions: } \\ \text { (2015) } & \begin{array}{l}\text { Creative, sustainable, and competitive } \\ \text { city policies in buenos aires }\end{array}\end{array}$

Carré and

7 Fernández Is the green belt? Analysis of urban (2013)

Núñez

8 Barelli

(2013)

and Urban marks and social senses at issue.

San Carlos de Bariloche, Argentina 1966 - 1983

9 Roldán

(2013)

Arroyo

10 Montero (2000)

Source: Own elaboration.

Inventaries of desire municipal census Data gathered from census could be used by urban of Rosario, Argentina (1889-1910) governance to formulate an efficient urban branding

An efficient urban branding should emphasize a sustainable city image in order to overcome social, environmental and economic challenges, as in Rio de Janeiro.

City brands could be associated with the urban economy to develop new economic opportunities. Thus, urban image could be a tool to promote and induce urban development, as in Florianópolis. (hegemonic) and a counter city brand (counter hegemonic) during mega-events, such as 2014 FIFA World Cup and 2016 Olympics.

Urban branding could be useful to urban management in terms of market-orientation and value-orientation in order to foster a fairer urban development, e.g. the creative and sustainable branding in Buenos Aires.

Urban projects and infrastructure could be an essential part of urban branding, e.g. a green belt in Buenos Aires.

Cultural factors influence the constitution of urban branding, which could be positive, negative and so on. Urban stakeholders could encourage and develop desired behaviors in cities, e.g. cordiality and ethically-related attitudes.

Note: All of these documents are papers published in journals indexed on the Scopus database.

The following topic discusses theoretical contributions about urban image in the Mercosur countries taking into account the papers selected in the RS. After that, we discuss what urban image is according to those selected papers as well as the challenges regarding the urban image in the cities of Mercosur countries. 


\subsection{Synthesis of theoretical contributions about urban image in Mercosur context}

An agenda composed of inclusiveness, socioeconomic opportunities, sustainability and urban smartness have been considered important to urban governance using urban branding and city branding for urban image improvement, and thus, promoting a sustainable urban development. Scholvin and Van Der Westhuizen (2019) argued for an equitable image of the city, in order that the attractiveness of cities not only be sustained by mega-events, in which they actually are. In other words, an efficient urban branding should emphasize a sustainable image of the city at all dimensions of sustainability (i.e. social, economic, and environmental), in this way, a positive image related to a good place to live and to work in, in which all city dwellers have the same opportunity and basic conditions of well-being. On urban infrastructure, Carré and Fernández (2013) demonstrated that some urban projects on urban infrastructure could be a representation of the city, which could be an essential part of its urban brand, e.g. in Buenos Aires, the cinturón ecológico (i.e. green belt) is considered a landmark of its branding.

Urban governance should consider the urban economy, urban planning, urban infrastructure, culture, and social capital as essential parts to be connected with urban branding. According to Yigitcanlar et al. (2018), the brand of the city could be associated with the urban economy, in this way, changing the urban brand could be a step toward new economic opportunities. For instance, the city of Florianópolis, Brazil, has changed its branding from a mere touristic approach to a smart innovative city view in order to attract industries and social capital, which is based on a knowledge economy rather than a resource-based economy. Even more, Núñez and Barelli (2013) revealed that cultural factors influence the constitution of urban branding, which could be positive, negative and so on, e.g. on how residents have dealt with migration and cases of xenophobia could make a negative image of the city of San Carlos de Bariloche.

However, sometimes urban branding can be a tool for political marketing and can have a negative aspect of "commoditization" of the urban culture, nonetheless institutional and legal topics should be taken into account when making and managing urban branding in an appropriate manner in order to legitimize urban policies, and promote an urban fair competitiveness. Dinardi (2017, p. 3) pointed out that, for instance, in Buenos Aires, Argentina, "while the creation of the city brand has been institutionalised and its formal features and use are regulated, in practice the brand escapes formal, legal regulations". As for Maiello and Pasquinelli (2015), they found two contrasting city brands of Rio de Janeiro during megaevents, a positive official city brand created by governments and industries, and a realistic 
counter official city brand by social movements and other urban stakeholders claiming for rights.

Thus, in order to deal with these problems, Lederman (2015) argued for a more positive socioeconomic perspective, in which urban branding could be useful not only under marketorientation, but also value-orientation of the urban brand could be helpful in providing a fairer urban development, as in the case of creative and sustainable branding in Buenos Aires, Argentina, so that, even a competitive development is also incentived in this scenario. Aligned with the positive socioeconomic perspective in urban branding suggested by Lederman (2015), it will also be useful to retain citizens in the city by increasing a positive evaluation of the city branding (Zucco et al., 2017).

In order to attract more investments, integrate businesses goals with the urban management, and increase the urban competitiveness, urban management could also integrate branding to city master plans and other urban planning tools for urban governance (Arroyo \& Montero, 2000). Furthermore, Roldán (2013) has shown that data gathered from census could be used by urban governance to formulate an efficient urban branding. Social, environmental, economic and demographic data provides information on the aspirations of the urban stakeholders, and then, a more attractive and satisfactory urban branding could be achieved.

Overall, in terms of urban image as a tool for urban governance within the Mercosur context, the literature has shown that urban managers and urban stakeholders can improve the urban image by increasing socioeconomic opportunities, promoting smart and sustainable cities, and looking for convergence among urban stakeholders. Also, the stakeholders involved in urban governance should consider connecting urban economy, urban planning, urban infrastructure, culture, and social capital to urban branding management in order to improve the urban image, and thus, to promote a desirable urban development. These synthesized findings have been aligned with Lucarelli and Berg (2011), Rehan (2014), Zucco et al. (2017), and Beck and Storopoli (2021) on the importance of urban image in urban governance in terms of urban attractiveness, stakeholder satisfaction, and decision-making of urban stakeholders and urban managers.

\subsection{Urban image in Mercosur: how it is and how it should be}

Urban image could be exploited to foster urban development and to meet urban stakeholder needs by urban governance. Scholvin and Van Der Westhuizen (2019), Lederman (2015), and Arroyo and Montero (2000) understand the urban image as a way used by cities to 
attract several kinds of business, national and international investments, creative people, and higher quality of social capital, and then, promoting an urban development in which reflects a creative, sustainable and competitive city. A positive urban image assumes that cities should be a space of competitiveness and consumption (Arroyo \& Montero, 2000), and a positive urban image plays a critical role in city dwellers' intention to remain living in the city (Zucco et al., 2017). In the same way, Yigitcanlar et al. (2018) interpret urban image as a tool to promote and induce urban development, which changes how a city is perceived in such a way that the urban economy could be changed to a desired one, and then, diversifying urban economic activities and achieving a sustainable and leading cities to more independent economic performance.

However, convergence among urban stakeholders about urban image can often be hardly achieved. According to Dinardi (2017, p. 11), urban image is hard to be classified as a whole: "Different understandings of culture, in turn, underpin contrasting imagined cities, and who inhabits the dominant image of the city will depend on who has the power to represent it". For instance, in Buenos Aires, Argentina, there are a lot of urban images that depend upon the socio-economic status, the cultural roots, the beliefs, and the kind of stakeholder (e.g. tourist, business, resident, etc...).

Aligned with Dinardi (2017), Maiello and Pasquinelli (2015) studied the cases of 2014 FIFA World Cup and 2016 Olympics, finding two different interpretations of the image of Rio de Janeiro city - the official brand and the counter brand: (1) on the one hand, the official brand was led by the government and the industry, in which the city image was very positive and beautiful; (2) on the other hand, the counter brand was led by social movements claiming for rights and better living conditions, in which the city image was real and counter hegemonic. Thus, the result from this myriad of interpretations on urban images is the competition among several different interests, and more effort to constitute a consensus of urban branding to be chosen: "These different interpretations of culture and competing urban visions impact on the ways social inclusion goals are mobilised and actually pursued." (Dinardi, 2017, p. 13).

Urban governance should consider tangible and intangible aspects in urban image management. On the one hand, tangible and physical aspects as well as urban infrastructure matter for urban image, Carré and Fernández (2013) understand that the urban image could be partially stemmed from urban infrastructure projects. On the other hand, intangible aspects of the cities are also important, such that, Núñez and Barelli (2013) pointed out that the image of the cities are not only created by tangible and physical aspects, but also are created by intangible, psychological and behavioral ones. Moreover, Roldán (2013) asserts that the urban 
image should reflect social, environmental, economic and demographic issues in order to satisfy and attract more residents, tourists, businesses and industries. In other words, the features and characteristics of the cities matter when building the urban image.

In essence, although a positive urban image can foster urban development and increase the performance of urban governance in terms of stakeholder needs satisfaction, convergence about what urban image is and how it should be is very difficult to achieve. Since there have been many stakeholders in urban governance, city and urban image could have different meanings, feelings, and purposes for the most different stakeholder groups. In mercosur context, institutional city brands have not been concrete for many urban stakeholders as well as the existence of official and counter-official city brandings has compromised city branding and urban image legitimacy (e.g. Dinardi, 2017; Maiello \& Pasquinelli, 2015). Also, tangible and intangible aspects in urban image management should also be explored and exploited by urban governance.

\subsection{The challenges of urban image in Mercosur}

As located in developing countries, cities of Mercosur have to face enormous socio-economic inequality challenges. Considering the role of urban branding in urban governance and development, urban image should be well managed in order to effectively attract the city target audience and meet the needs of the urban stakeholders. For instance, Scholvin and Van Der Westhuizen (2019) illustrated the Brazilian case of Rio de Janeiro, which has to deal with social inequality, disparity between very rich and very poor people, and the lack of opportunities for all of its city dwellers.

In this way, building an efficient urban image could help the urban governance to overcome urban socioeconomic, environmental and ethically-related challenges (Yigitcanlar et al., 2018). An efficient urban image should consider (Yigitcanlar et al., 2018; Núñez \& Barelli, 2013; Roldán, 2013): (1) how the urbanization processes have been developed over time (e.g. population increase and gentrification);(2) urban occupation legality or illegality (e.g. slums and favelas); (3) sustainable mobility; (4) environmental issues, safety and security issues; (5) ethically-related issues, misconduct of public managers; (6) how the urban image has been recognized, perceived and seen by others either at the local level, national level or international level, disregarding if they are or not urban stakeholders in urban governance; (7) ethical use of data in urban branding management; and (8) encouraging desired city dwellers' behaviors, e.g. receiving cordially new migrants and having other attitudes ethically-related. 
Urban socioeconomic issues and urban processes are oftentimes uncertain and complex, which concern a plethora of urban stakeholders in multiple urban themes. The actual urban image and the desired one will vary depending upon the kind of urban stakeholder. For this reason, urban governance should consider: (1) responding in a balanced way to pressures from market and non-market segments is another challenge of urban governance, because prioritizing the needs of the citizens, businesses and tourists simultaneously is mandatory (Lederman, 2015); (2) since urban processes are difficult to interpret due to their uncertainty and complexity, urban branding should be carefully made and strategized (Arroyo \& Montero, 2000); (3) creating an inclusive urban image through stakeholder engagement, which is resulted from consensus among stakeholders (Dinardi, 2017); and finally, (4) managing a profit-making urban image that does not loose cultural and social aspects of cities, for instance, avoiding the mere "consumerization" of the urban culture by tourists (Dinardi, 2017).

There is also a conflict between what an urban image aims to demonstrate and what it actually is. Thus, demonstrating an actual positive urban image of a sustainable, democratic and prosperous city could be one of the major challenges in Mercosur cities. The studies of Carré and Fernández (2013) and Maiello and Pasquinelli (2015) exemplify such a conflict:

- Carré and Fernández (2013) pointed out that the cinturón ecológico (i.e. green belt) in Buenos Aires, was created under the modernist school of urbanism. Although it theoretically tried to preserve green areas around the city, it is not sustainable. Because it motivates citizens to overuse private cars and creates an imaginary urban image for the city that green areas within urban districts are no longer necessary such that green areas are already preserved around the city;

- Maiello and Pasquinelli (2015) revealed that, in mega-events occurred in Rio de Janeiro, the official city branding created by urban management, governments, and main industrial players try to show a positive urban image, hiding socioeconomic and environmental issues struggled by ordinary urban stakeholders, e.g. citizens, and small businesses. Although the official city branding is called "official", it does not reflect the actual city conditions, therefore its legitimacy is fragilized.

In brief, urban governance challenges about urban image in Mercosur countries are especially related to socioeconomic disparities, environmental, and ethical issues. On the 
whole, urban stakeholders in urban governance should improve urban image, foster a prosperous urban development by managing an urban image through the consensus among all urban stakeholders, converging the actual to the desired urban image, and encouraging city dwellers to have desired behaviors to lead city image into a more positive one.

\section{Conclusions}

We achieved the research purpose by analyzing and synthesizing the knowledge structure related to city image as a tool for urban governance within the Mercosur context. For this purpose, our research synthesis focused on the theoretical contributions, the ontological and deontological urban image understanding, and the regional challenges in Mercosur cities.

Our findings findings reveal that: (1) in terms of theoretical contributions, aligned with the seminal research in urban branding, research on urban image in Mercosur context has shown that socioeconomic opportunities and inclusiveness, sustainability, smartness, stakeholder convergence and satisfaction, and city attractiveness are essential parts of urban image as an urban governance tool for sustainable urban development; (2) consensus on deontological and ontological urban image among stakeholders in urban governance is needed to ensure an integrated and legitimate urban image, which would be commonly accepted by all urban stakeholders taking either tangible (e.g. infrastructure, urban design, etc.) or intangible aspects of cities (e.g. social, behavioral, cultural, etc.); and (3) in terms of urban image in Mercosur context, urban governance challenges are mainly on issues related to socioeconomic disparities, environmental, and ethical concerns.

The originality of this paper is applying a research synthesis to analyze the knowledge structure related to the image of the cities as a tool for urban governance within the Mercosur context. Our theoretical contributions lie not only in the endorsement of urban branding seminal research by the research on urban image in Mercosur context, but also in terms of the regional challenges as well as the deontological and ontological different perspectives from many urban stakeholders in urban governance of Mercosur cities.

Practitioners, such as urban planners, urban managers, and policy-makers of most varied urban affairs could benefit from the framework developed in this study. Practitioners should consider urban stakeholder expectations and needs in city image management in order to strengthen democratic institutions, create consensus among urban stakeholders, foster sustainable urban development, and overcome regional challenges. 
The social contributions of this study lie in clarifying how a positive urban image could improve the relationship among urban stakeholders in urban governance of cities in Mercosur countries, and in shedding light on how stakeholder-orientation has been mandatory to assure convergence of urban stakeholders about how urban image is and how it should be in Mercosur cities. Thus, regional and local communities gain more satisfaction of living in their places as well as urban governance based on bottom-up approaches.

Our agenda for future studies suggests the need of: (1) evaluating city brand and urban image strategies in terms of their effectiveness in emerging countries, such as in Mercosur context (Florek et al., 2021); (2) exploring how urban processes and urban products can be used to improve urban image, specially in smart cities (Beck \& Conti, in press; Yigitcanlar et al., 2018); (3) exploring the constructs of stakeholder, stakeholder salience, and value creation in urban branding, city branding, urban image, city image management (Beck \& Storopoli, 2021) and in country branding in terms of image and reputation (Mariutti \& Giraldi, 2020); (4) understanding what is the possible relationship between country branding perception and city branding perception, and how stakeholder-orientation moderates it in urban governance; and (5) exploring the role of stakeholder-orientation and resource-based view in urban governance for city brand equity and urban image equity (Górska-Warsewicz, 2020; Hanna et al., 2021; Beck \& Storopoli, 2021; Freeman, Dmytriyev, \& Phillips, in press).

The main limitation of this study is that we extract data only from the Scopus database, which is considered the most comprehensive database in urban studies and social sciences. Thus, further research should consider other databases, e.g. Web of Science. As our research synthesis has a systematic procedure of data collection, some studies could be out of the sample because the database returns only documents containing the terms used in the search expressions in the titles, abstracts, and keywords.

\section{References}

Aguinis, H., Ramani, R. S., \& Alabduljader, N. (2017). What You See Is What You Get? Enhancing Methodological Transparency in Management Research. Academy of Management Annals, 12(1), 83-110. https://doi.org/10.5465/annals.2016.0011

Arroyo, M. F., \& Montero, N. A. (2000). To build the city: A paradigm of urban management. The proposal of a method to make urban plans viable. Revista Venezolana de Gerencia, 5(10), 91-109.

Ashworth, G., \& Kavaratzis, M. (2009). Beyond the logo: Brand management for cities. Journal of Brand Management, 16, 520-531. https://doi.org/10.1057/palgrave.bm.2550133 
Avraham, E., \& Ketter, E. (2008). Media Strategies for Marketing Places in Crisis: Improving the image of Cities, Countries and Tourist destinations. Elsevier: Amsterdam.

Beck, D., \& Storopoli, J. (2021). Cities through the lens of Stakeholder Theory: A literature review. Cities, 118, 103377. https://doi.org/10.1016/j.cities.2021.103377

Beck, D. F. \& Conti, D. M. (in press). The Role of Urban Innovativeness, Smart Governance, and Smart Development in the Urban Smartness. Humanidades \& Inovação.

Braun, E., Kavaratzis, M., \& Zenker, S. (2013). My city - my brand: The different roles of residents in place branding. Journal of Place Management and Development, 6(1), 18-21. https://doi.org/10.1108/17538331311306087

Campelo, A. (2015). Rethinking Sense of Place: Sense of One and Sense of Many. In: Kavaratzis, M., Warnaby, G., \& Ashworth, G. J. (eds). Rethinking Place Branding: Comprehensive brand development for cities and regions (pp. 51-60). Cham: Springer.

Cañizares, S. M. S., Tabales, J. M. N., \& Garcia, F. J. F. (2014). Local residents' attitudes towards the impact of tourism development in Cape Verde. Tourism \& Management Studies, 10(1), 87-97.

Carré, M., \& Fernández, L. (2013). Is the green belt? Analysis of urban brand that never existed. Eure, 39(117), 49-68. https://doi.org/10.4067/S0250-71612013000200003

Cooper, H. (2017). Research synthesis and meta-analysis (5th ed.). Thousand Oaks: SAGE Publications, Inc.

Dinardi, C. (2017). Cities for sale: Contesting city branding and cultural policies in Buenos Aires. Urban Studies, 54(1), 85-101. https://doi.org/10.1177/0042098015604079

Evans, G. (2015). Rethinking Place Branding and Place Making Through Creative and Cultural Quarters. In: Kavaratzis, M., Warnaby, G., \& Ashworth, G. J. (eds). Rethinking Place Branding: Comprehensive brand development for cities and regions (pp. 135-158). Cham: Springer.

Florek, M., Hereźniak, M., \& Augustyn, A. (2021). Measuring the effectiveness of city brand strategy. In search for a universal evaluative framework. Cities, 110, 103079. https://doi.org/10.1016/j.cities.2020.103079

Florek, M., Insch, A., \& Gnoth, J. (2006). City council websites as a means of place brand identity communication. Place Branding, 2(4), 276-296.

https://doi.org/10.1057/palgrave.pb.6000036

Florek, M., \& Kavaratzis, M. (2014). From brand equity to place brand equity and from there to the placebrand. Place Branding and Public Diplomacy, 10(2), 103-107.

https://doi.org/10.1057/pb.2014.9

Fouts, J. S. (2010). Social Media and Immersive Worlds: Why International Place Branding Doesn't Get Weekends Off. In: Go, F. M., \& Govers, R. (eds.). International Place 
Branding Yearbook 2010: Place Branding in the New Age of Innovation (pp. 113-119) New York: Palgrave Macmillan.

Freeman, R. E., Dmytriyev, S. D., \& Phillips, R. A. (in press). Stakeholder theory and the resource-based view of the firm. Journal of Management.

https://doi.org/10.1177/0149206321993576.

Górska-Warsewicz, H. (2020). Factors Determining City Brand Equity-A Systematic Literature Review. Sustainability, 12(19), 7858. https://doi.org/10.3390/su12197858

Govers, R., \& Go, F. M. (2010). The E-branding of Places. In: Go, F. M., \& Govers, R. (eds.). International Place Branding Yearbook 2010: Place Branding in the New Age of Innovation (pp. 121-133) New York: Palgrave Macmillan.

Green, A., Grace, D., \& Perkins, H. (2016). City branding research and practice: An integrative review. Journal of Brand Management, 23(3), 252-272.

https://doi.org/10.1057/bm.2016.8

Halemane, M., Janszen, F., \& Go, F. M. (2010). Orchestrating the Innovation Process of Place Branding. In: Go, F. M., \& Govers, R. (eds.). International Place Branding Yearbook 2010: Place Branding in the New Age of Innovation (pp. 172-183) New York: Palgrave Macmillan.

Hanna, S. A., \& Rowley, J. (2015). Rethinking Strategic Place Branding in the Digital Age. In: Kavaratzis, M., Warnaby, G., \& Ashworth, G. J. (eds). Rethinking Place Branding: Comprehensive brand development for cities and regions (pp. 85-100). Cham: Springer.

Hanna, S., Rowley, J., \& Keegan, B. (2021). Place and Destination Branding: A Review and Conceptual Mapping of the Domain. European Management Review, 18(2), 105-117. https://doi.org/10.1111/emre.12433

Hankinson, G. (2015). Rethinking the Place Branding Construct. In: Kavaratzis, M., Warnaby, G., \& Ashworth, G. J. (eds). Rethinking Place Branding: Comprehensive brand development for cities and regions (pp. 13-32). Cham: Springer.

Kavaratzis, M., \& Ashworth, G. J. (2005). City Branding: An effective assertion of identity or a transitory marketing trick? Journal of Economic and Social Geography, 96(5), 506-514. https://doi.org/10.1111/j.1467-9663.2005.00482.x

Kavaratzis, M. (2005). Place Branding: A Review of Trends and Conceptual Models. The Marketing Review, 5(4), 329-342. https://doi.org/10.1362/146934705775186854

Kavaratzis, M., \& Hatch, M. J. (2013). The dynamics of place brands: An identity-based approach to place branding theory. Marketing Theory, 13(1), 69-86. https://doi.org/10.1177/1470593112467268

Kerr, G., \& Oliver, J. (2015). Rethinking Place Identities. In: Kavaratzis, M., Warnaby, G., \& Ashworth, G. J. (eds). Rethinking Place Branding: Comprehensive brand development for cities and regions (pp. 61-72). Cham: Springer. 
Kotler, P., Haider, D. H., \& Rein, I. (1993). Marketing places: attracting investment, industry, and tourism to cities, states, and nations. New York: The Free Press.

Lederman, J. (2015). Urban fads and consensual fictions: Creative, sustainable, and competitive city policies in Buenos Aires. City and Community, 14(1), 47-67. https://doi.org/10.1111/cico.12095

Lucarelli, A., \& Berg, P. O. (2011). City branding: a state-of-the-art review of the research domain. Journal of place management and development, 4(1), 9-27. https://doi.org/10.1108/17538331111117133

Lucarelli, A., \& Giovanardi, M. (2016). The political nature of brand governance: a discourse analysis approach to a regional brand building process. Journal of Public Affairs, 16(1), 1627. https://doi.org/10.1002/pa.1557

Maiello, A., \& Pasquinelli, C. (2015). Destruction or construction? A (counter) branding analysis of sport mega-events in Rio de Janeiro. Cities, 48, 116-124. https://doi.org/10.1016/j.cities.2015.06.011

Mariutti, F.G., \& Tench, R. (2016). How does Brazil measure up? Comparing rankings through the lenses of nation brand indexes. Place Branding and Public Diplomacy, 12(1), 17-31. https://doi.org/10.1057/pb.2015.19

Mariutti, F. G. (2017). The placement of country reputation towards place management. Journal of Place Management and Development, 10(3), 240-253. https://doi.org/10.1108/JPMD-10-2016-0067

Mariutti, F. G., \& Giraldi, J. M. E. (2019). Country brand personality of Brazil: a hindsight of Aaker's theory. Place Branding and Public Diplomacy, 16, 1-14. https://doi.org/10.1057/s41254-019-00153-3

Mariutti, F. G., \& Giraldi, J. M. E. (2020). Country brand equity: The role of image and reputation. Brazilian Administration Review, 17(3), e180128. https://doi.org/10.1590/18077692 bar2020180128

Morgan, N., \& Pritchard, A. (2001). Advertising in Tourism \& Leisure. Woburn: ButterworthHeinemann.

Núñez, P. G., \& Barelli, A. I. (2013). Urban marks and social senses at issue. San Carlos de Bariloche, Argentina 1966 - 1983. HiSTOReLo, 5(10), 164-196.

Oliveira, E. (2015). Place branding as a strategic spatial planning instrument. Place Branding and Public Diplomacy, 11(1), 18-33. https://doi.org/10.1057/pb.2014.12

Oguztimur, S., \& Akturan, U. (2016). Synthesis of city branding literature (1988-2014) as a research domain. International Journal of Tourism Research, 18(4), 357-372.

https://doi.org/10.1002/jtr.2054 
Pedeliento, G., \& Kavaratzis, M. (2019). Bridging the gap between culture, identity, and image: A structurationist conceptualization of place brands and place branding. Journal of Product \& Brand Management, 28 (30), 348-363. https://doi.org/10.1108/JPBM-01-20181735

Pierre, J. (2011). The Politics of Urban Governance. Hampshire: Palgrave Macmillan.

Rehan, R. M. (2014). Urban branding as an effective sustainability tool in urban development. HBCR Journal, 10(2), 222-230. https://doi.org/10.1016/j.hbrcj.2013.11.007

Roldán, D. P. (2013). Inventaries of desire municipal census of Rosario, Argentina (18891910). História (São Paulo), 32(1), 327-353. https://doi.org/10.1590/s010190742013000100018

Scholvin, S., \& van der Westhuizen, J. (2019). Cape Town and Rio de Janeiro: Attractive world cities and their dark sides. Geographische Rundschau, 71(11), 44-49.

Skinner, H. (2008). The emergence and development of place marketing's confused identity. Journal of Marketing Management, 24(9-10), 915-928. https://doi.org/10.1362/026725708X381966

Yigitcanlar, T., Sabatini-Marques, J., Lorenzi, C., Bernardinetti, N., Schreiner, T., Fachinelli, A., \& Wittmann, T. (2018). Towards smart florianópolis: What does it take to transform a tourist island into an innovation capital? Energies, 11(12), art. No. 3265. https://doi.org/10.3390/en11123265

Zenker, S., Braun, E., \& Petersen, S. (2017). Branding the destination versus the place: The effects of brand complexity and identification for residents and visitors. Tourism Management, 58, 15-27. https://doi.org/10.1016/j.tourman.2016.10.008

Zucco, F. D., Reis, C., Anjos, S. J. G., Effting, S. J., \& Pereira, M. L. (2017). Attributes of the Blumenau (Brazil) brand from the residents' perspective, and its influence on the decision to stay in the destination. International Journal of Tourism Cities, 3(1), 43-55. https://doi.org/10.1108/IJTC-10-2016-0044. 


\title{
IMAGEM DAS CIDADES COMO FERRAMENTA PARA A GOVERNANÇA URBANA NO MERCOSUL: CONTRIBUIÇÕES DA MARCA DE CIDADE E URBANA $^{1}$
}

\author{
Donizete Ferreira Beck \\ Universidade Nove de Julho - UNINOVE. \\ São Paulo, SP - Brasil. \\ donizetebeck@uni9.edu.br \\ Marcos Ferasso \\ Universidade Autónoma de Lisboa - UAL. \\ Lisboa, Lisboa - Portugal. \\ admmarcosferasso@gmail.com
}

Objetivo: Analisar a estrutura intelectual relacionada à imagem das cidades como uma ferramenta para governança urbana no contexto do Mercosul.

Método: Utilizou-se uma síntese de pesquisa para analisar e discutir (1) contribuições teóricas, (2) deontologia e ontologia da imagem urbana, e (3) os desafios da imagem urbana como ferramenta para a governança urbana no contexto do Mercosul.

Originalidade / Relevância: Sintetizamos as contribuições teóricas, o entendimento deontológico e ontológico da imagem urbana e os desafios da imagem urbana sob a marca de cidades e marca urbana como uma ferramenta para a governança no contexto do Mercosul.

Resultados: A síntese sobre a imagem urbana no contexto do Mercosul revela que: (1) a pesquisa regional está alinhada com a seminal ao convergirem que inclusão socioeconômica, sustentabilidade, inteligência urbana, convergência e satisfação entre stakeholders, e sustentabilidade são partes essenciais da imagem urbana de uma governança urbana que promove o desenvolvimento urbano sustentável; (2) a imagem urbana é uma ferramenta que promove o desenvolvimento, a gestão e a governança urbana, a qual possui distintas interpretações e anseios por diferentes stakeholders urbanos; e (3) discute-se sobre os principais desafios regionais.

Contribuições Teóricas / Metodológicas: Reforçamos os argumentos das pesquisas seminais sobre o papel da imagem urbana na governança urbana por meio de uma síntese de pesquisa sobre a imagem urbana no contexto do Mercosul, considerando as perspectivas e os desafios regionais.

Contribuições Sociais / Gerenciais: Comunidades locais e regionais têm suas necessidades atendidas, uma governança urbana, desenvolvimento sustentável e democracia são encorajados na governança urbana.

Palavras-chave: Cidade. Urbano. Marca. Imagem. Mercosur. Development. Governance.

\section{$\underline{\text { Como citar }}$}

American Psychological Association (APA)

Beck, D. F., \& Ferasso, M. (2022, jan./mar.). Imagem das cidades como ferramenta para a governança urbana no Mercosul: contribuições da marca de cidade e urbana. Revista Brasileira de Marketing - ReMarK, 21(Num. Esp.), 9-29. https://doi.org/10.5585/remark.v21i1.19354.

1 "Esta pesquisa recebeu apoio financeiro parcial do governo de Israel por meio do Council for Higher Education (CHE, המועצה להשכלה גבוהה, Israel) e apoio financeiro parcial da 'Coordenação de Aperfeiçoamento de Pessoal de Nível Superior' (CAPES, Brazil)." 


\section{Introdução}

O mundo tornou-se ainda mais urbanizado, mais pessoas vivem dentro das cidades e as cidades estão se tornando parte do sentimento de pertencimento das pessoas (Pedeliento \& Kavaratzis, 2019; Zenker, Braun, \& Petersen, 2017; Kotler, Haider, \& Rein, 1993). Então, a imagem e a marca das cidades constituem não apenas uma mera imagem de um lugar, mas também um reflexo dos valores comuns, cultura, comportamento, modo de pensar, e até reflete a personalidade dos habitantes da cidade (Evans, 2015; Kerr \& Oliver, 2015; Kotler et al., 1993; entre outros). Uma razão para este fenômeno é que as cidades têm mais condições de proporcionar uma melhor qualidade de vida para as pessoas do que as áreas rurais, e as pessoas têm desenvolvido simultaneamente sentimentos em relação a seus lugares (Kerr \& Oliver, 2015; Morgan \& Pritchard, 2001).

Mais importante ainda, as percepções psicológicas sobre a marca e imagem urbana de todos os tipos de pessoas, como residentes, turistas e indústrias, são um dos pilares que explicam o sucesso ou o fracasso do desenvolvimento urbano (Avraham \& Ketter, 2008; Kotler et al., 1993). Neste sentido, uma imagem positiva da cidade possui uma função de atração de um desenvolvimento urbano desejável, bem como atrair stakeholders urbanos, pessoas, investimentos e empresas, de modo que a cidade tenha uma economia dinâmica e mais prosperidade (Avraham \& Ketter, 2008; Cañizares, Tabales, \& Garcia, 2014; Kotler et al., 1993; Oliveira, 2015; Beck \& Storopoli, 2021). Assim, a imagem urbana pode ser uma ferramenta para a governança urbana (Lucarelli \& Berg, 2011).

No Hemisfério Sul, o Mercosul (i.e. Mercado Comum do Sul) é uma organização intergovernamental e um bloco de livre comércio, com a possibilidade de futuramente se tornar uma união supranacional. A importância de estudar a marca e a imagem urbana no contexto dos países do Mercosul é que esses países - Argentina, Brasil, Paraguai, Uruguai e Venezuela são países em desenvolvimento, e a marca de lugar, como a marca urbana, poderia ser útil para superar desafios enfrentados por cidades desses países. Isto pode resultar em um melhor desenvolvimento urbano, maiores taxas de emprego e também um melhor padrão de vida e melhores condições de vida.

No Brasil, um país do Mercosul, muitos estudos mostraram o papel importante desempenhado pela imagem nacional em sua reputação, desenvolvimento e identidade (Mariutti \& Tench, 2016; Mariutti, 2017; Mariutti \& Giraldi, 2019; Mariutti \& Giraldi, 2020), mas pouco se sabe sobre o papel da imagem das cidades no Brasil e em outros países do 
Mercosul. Portanto, o objetivo deste estudo é analisar a estrutura intelectual relacionada à imagem das cidades como uma ferramenta para governança urbana no contexto do Mercosul.

Realizamos uma Síntese de Pesquisa (Cooper, 2017), considerando três objetivos específicos relacionados à imagem urbana como uma ferramenta de governança urbana dentro do contexto do Mercosul: (1) contribuições teóricas, (2) entendimentos ontológicos e deontológicos da imagem urbana, e (3) desafios regionais. Este artigo se limita apenas à imagem urbana dentro do contexto do Mercosul, no entanto, o estado da arte sobre a marca da cidade já foi amplamente explorado na academia, como os trabalhos de Hanna, Rowley e Keegan (2021), de Górska-Warsewicz (2020), de Oguztimur e Akturan (2016), de Green, Grace e Perkins (2016), e de Lucarelli e Berg (2011).

Embora pouco se saiba e não existam muitas publicações sobre marca urbana no contexto dos países do Mercosul, nossos resultados derivam de uma análise de 10 publicações que fornecem uma estrutura rica de contribuições, a qual deve ser considerada por gestores públicos e stakeholders urbanos na governança urbana para melhorar a imagem urbana e a estrutura política, e também, fomentar o desenvolvimento socioeconômico urbano (Pierre, 2011; Cañizares et al., 2014; Oliveira, 2015; Lucarelli \& Giovanardi, 2016; Beck \& Storopoli, 2021). Por isso, o sucesso das cidades é o sucesso das indústrias, dos cidadãos que moram nas cidades, e de todos stakeholders urbanos. Ou seja, a imagem urbana é importante.

O tópico seguinte explica o que é marca e imagem urbana, bem como explora o que a literatura tem publicado sobre marca e imagem urbana. Em seguida, detalhamos o método utilizado nesta pesquisa. Depois disso, apresentamos nossos resultados e os discutimos com a literatura. Por fim, concluímos este artigo ao sintetizar seus principais achados, apresentamos as limitações da pesquisa e propomos algumas sugestões para estudos futuros.

\section{Imagem urbana e marca urbana}

Marca urbana (urban branding) é o ato de promover cidades com a finalidade de atrair mais investimentos, indústrias, turistas e moradores da cidade, ou seja, promover um desenvolvimento urbano desejado pela governança urbana, em que determinada cidade compete saudavelmente com outras cidades. De acordo com Kotler, Haider, e Rein (1993), as cidades podem explorar melhor sua marca para superar problemas socioeconômicos diversos, ou seja, a marca urbana pode ser usada para promover o desenvolvimento urbano e evitar que as cidades percam seu dinamismo socioeconômico. Ao fazer isso, as cidades se tornam mais atraentes e evitam a migração de pessoas, negócios, turismo, convenções e indústrias, bem 
como desenvolver estratégias para não aumentar impostos. Além disso, as cidades são consideradas objetos de consumo, em que pessoas e empresas se comparam e tentam encontrar as melhores cidades para viver ou investir (Avraham \& Ketter, 2008).

Avraham e Ketter (2008) destacaram que a marca urbana é, geralmente, utilizada na gestão do turismo, para que uma cidade lidere em um determinado nicho turístico, no qual alguns conceitos de marca (branding) do marketing são utilizados, e.g. aqueles relacionados ao design, valores, identidade e estratégia de imagem. Portanto, o posicionamento de lugar (place positioning) é uma preocupação central dos acadêmicos e praticantes sobre a marca do local (place branding), neste caso, aplicando-a às cidades.

Segundo Hankison (2015), a cerne da marca do lugar é possui seis eixos: Imagem de marca ou brand image (e.g. Pedeliento \& Kavaratzis, 2019; Mariutti \& Giraldi, 2020), posicionamento e patrimônio da marca (e.g. Florek \& Kavaratzis, 2014; Mariutti \& Giraldi, 2020; Górska-Warsewicz, 2020), extensão da marca, arquitetura da marca, identidade e orientação da marca (e.g. Skinner, 2008; Florek, Insch, \& Gnoth, 2006; Zenker, Braun, \& Petersen, 2017; Pedeliento \& Kavaratzis, 2019). Embora este artigo não tenha como objetivo realizar um estudo quantitativo, foi importante mencionar esses construtos para melhor situar nosso leitor. Neste estudo, trabalhamos apenas no eixo da imagem de marca.

Por sua vez, marca da cidade (city branding) é, de acordo com Lucarelli e Berg (2011, p. 22, tradução nossa), um “domínio de pesquisa internacionalmente reconhecido e caracterizado por um alto nível de multidisciplinaridade, uma rápida proliferação dentro e entre disciplinas, e pouca fragmentação do seu arcabouço teórico". Também, é considerada uma ferramenta de governança urbana que conecta a imagem urbana percebida por moradores à comunicação governamental (Zucco et al., 2017). A diferença entre marca urbana (urban branding) e marca da cidade (city branding) é que a primeira é uma abordagem teórica que promove a sustentabilidade urbana, enquanto que a segunda é um aspecto da comunicação urbana que pode melhorar a imagem urbana (Rehan, 2014).

Quanto à imagem urbana (urban image), Kotler et al. (1993, p. 35, tradução nossa) afirmaram que a imagem urbana depende da "imagem atual e dos atributos reais" das cidades que podem ser positivos, fracos, negativos, mistos, contraditórios ou muito atrativos. A imagem urbana é "a soma de crenças, ideias e impressões que as pessoas possuem" da cidade (Kotler et al., 1993, p. 141, tradução nossa). Tais “imagens não são fáceis de serem desenvolvidas ou mudadas. Elas demandam pesquisa sobre como moradores e stakeholders de fora da cidade 
enxergam o lugar; (...) identificando os elementos verdadeiros e falsos, (...) elementos fortes e fracos, (...) imagem consensual (...)", dentre outros (Kotler et al., 1993, p. 37, tradução nossa).

O que importa é que marca urbana (urban branding) e marca da cidade (city branding) tem sido ferramentas úteis para gestores urbanos e stakeholders urbanos na governança urbana, na qual - a imagem - das cidades possui papel importante na atratividade urbana, satisfação dos stakeholders urbanos (e.g. cidadãos, negócios e indústrias), e na tomada de decisão de stakeholders urbanos e de gestores públicos (Lucarelli \& Berg, 2011; Rehan, 2014; Zucco et al., 2017; Beck \& Storopoli, 2021).

Existem três níveis de marketing de lugar (place marketing), de uma visão mais abrangente para uma mais estrita, são: (1) mercados alvo; (2) fatores de marketing; e (3) grupo de planejadores urbanos. Kotler et al. (1993) afirmam que quando as cidades estão selecionando seus mercados-alvo, o contexto em que estão localizadas deve ser levado em conta e, em seguida, fazer com que a marca urbana seja feita para atrair e satisfazer esses alvos. Desta forma, alguns exemplos de alvos são: turistas e conferencistas; exportadores; investidores; fabricantes; sedes de empresas; e novos residentes. Além disso, as cidades devem considerar os fatores de marketing que afetam a qualidade da marca urbana (urban branding), tais como a infraestrutura urbana, questões relacionadas às pessoas (por exemplo, cultura), atrações e eventos urbanos, e também, a imagem e a qualidade de vida urbana.

Desta forma, os planejadores urbanos identificam um diagnóstico, planejam uma visão e implementam as ações necessárias para promover a imagem urbana através do relacionamento entre cidadãos, governos e indústrias. Assim, as cidades podem explorar sua imagem, atrações, infra-estrutura e pessoas para atrair seus mercados-alvo, melhorar a governança urbana e satisfazer uma múltiplos stakeholders urbanos (Kotler et al., 1993; Avraham \& Ketter, 2008; Rehan, 2014; Zucco et al., 2017; Beck \& Storopoli, 2021).

Portanto, a imagem urbana direciona o processo de tomada de decisão das pessoas, empresas e turistas em relação às suas atividades urbanas e na governança urbana. Então, uma governança urbana eficiente explora os meios de comunicação de massa e as técnicas de campanhas de marketing a fim de manter ou mudar uma imagem urbana para ser bem sucedida, e então a realidade urbana (Avraham \& Ketter, 2008; Zucco et al., 2017). A Figura 1 ilustra uma síntese de como a imagem de marca no branding urbano pode afetar o desenvolvimento urbano. 


\section{Figura 1}

Uma Sintese da Importância da Imagem Urbana na Marca Urbana em Prol do Desenvolvimento Urbano

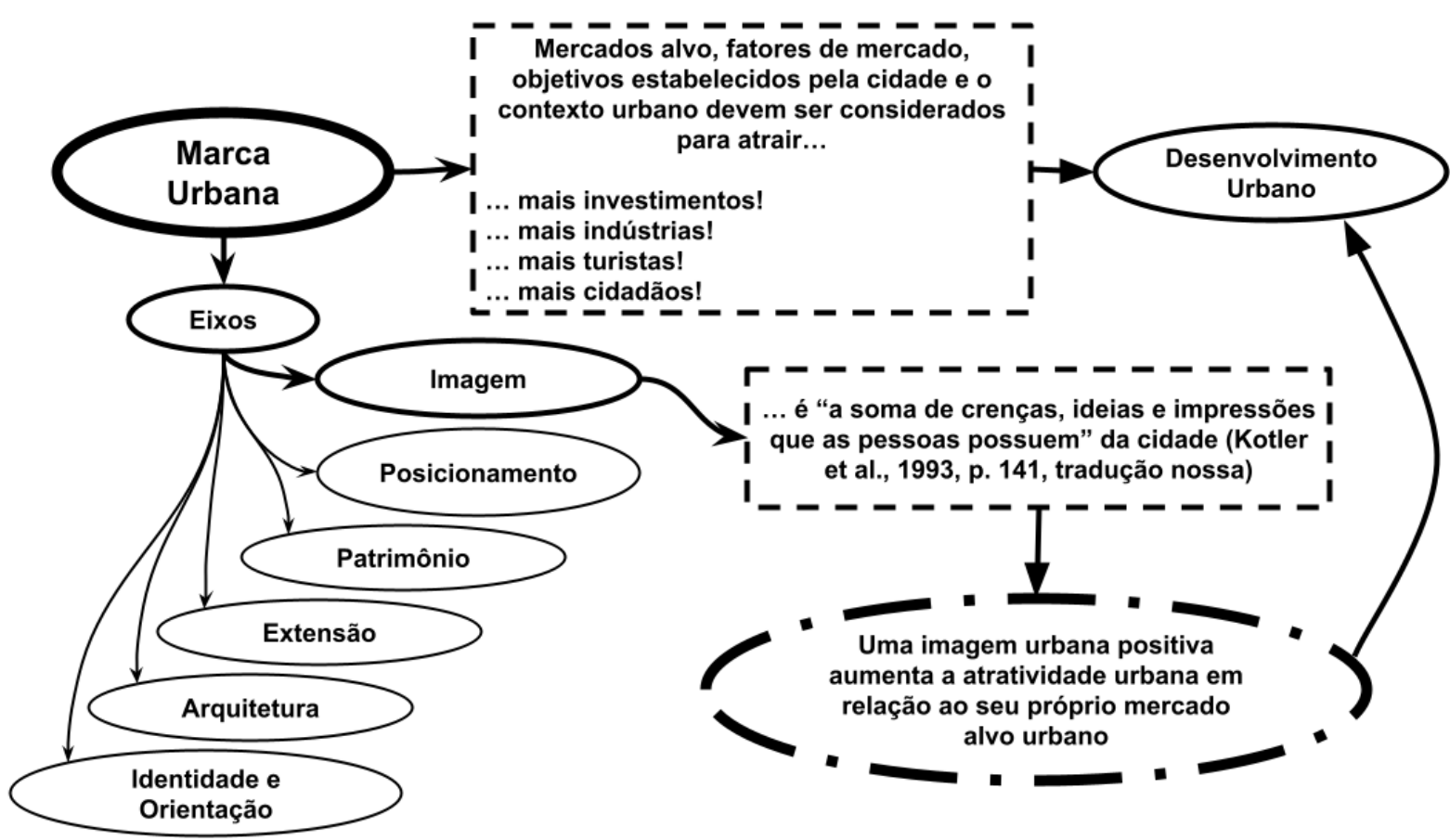

Fonte: Elaboração própria.

Alguns pesquisadores têm escrito sobre as tendências futuras do marketing de lugares (place branding), estas tendências estão vinculadas às Tecnologias de Informação e Comunicação (TICs), à digitalização, e à mudança do padrão de comunicação estratégica. Por exemplo, a marca de lugar possui processos que se prolongam o tempo todo e são contínuos dentro do contexto das mídias sociais digitais (Fous, 2010); e-branding e sua implementação nas cidades (Gover \& Go, 2010); o processo de inovação na marca de lugar (Halemane Janszen \& Go, 2010); as identidades de lugar no place branding (Kerr \& Oliver, 2015); o próprio construto de marca de lugar (Hankinson, 2015); o senso de lugar entre indivíduos (Campelo, 2015); o papel da internet e das estratégias digitais na marca de lugar (Hanna \& Rowley, 2015; Govers, 2015); cultura e criatividade (Evans, 2015). Dentre outros temas e abordagens relacionados ao que já tem sido demonstrado neste parágrafo desde a obra seminal de Kotler et al. (1993) sobre marca urbana e marketing de lugares.

Atualmente, os grupos de Mihalis Kavaratzis e Gregory Ashworth são alguns dos grupos mais influentes de acadêmicos sobre o tópico de marca de lugar e marca urbana 
devido ao alto impacto da publicação deles e às suas contribuições teóricas práticas e teóricas. Eles têm trabalhado nesta temática desde o início do século 21 até os dias de hoje sobre: A natureza da marca da cidade, analisando se ela tem uma afirmação efetiva da identidade do povo ou um truque positivista e transitório dos gerentes (Kavaratzis \& Ashworth, 2005); revisando tendências, medidas e modelos conceituais de marca de lugares, marca de origem, marca cultural, marca de entretenimento, marca de destino, e até mesmo marca corporativa (Kavaratzis, 2005); o papel de uma comunicação primária focada no comportamento da cidade no desenvolvimento de estratégias paisagísticas, projetos de infraestrutura e estrutura organizacional (Kavaratzis, 2005); a comunicação secundária no desenvolvimento de uma comunicação com objetivos principais a serem alcançados de forma diferente da primária (Kavaratzis, 2005); a importância do logotipo na marca urbana (Ashworth \& Kavaratzis, 2009); o dinamismo das marcas e identidades do lugar, que não são estáticas e exigem um diálogo permanente a fim de promover o consenso sobre a marca do lugar (Kavaratzis \& Hatch, 2013); sobre a importância do compromisso dos moradores e o sentimento de pertencer ao lugar (Braun, Kavaratzis \& Zenker, 2013); dentre outros estudos relevantes.

\section{Método}

A fim de atingir o objetivo da pesquisa, realizamos uma síntese de pesquisa (research synthesis) coletando dados do banco de dados da Scopus, que é considerado o banco de dados acadêmico mais abrangente em ciências sociais. As sínteses de pesquisa são formas rigorosas e transparentes de conduzir revisões de literatura para sintetizar achados variados e cumulativos na literatura sobre um tópico específico de pesquisa (Cooper, 2017). Em suma, sínteses de pesquisa possuem sete passos (Cooper, 2017): (1) formulação do problema; (2) busca da literatura; (3) obtenção dos dados e das informações dos estudos; (4) avaliação da qualidade dos estudos; (5) análise e integração dos resultados dos estudos; (6) interpretação das evidências; e (7) apresentação dos resultados. Neste estudo, o tópico específico de pesquisa está relacionado à imagem urbana na marca urbana como uma ferramenta para a governança urbana dentro do contexto do Mercosul.

Nossa expressão de busca considerou quaisquer possibilidades de termos relacionados à marca urbana, ao marketing urbano e ao marketing de lugar em todos os países do Mercosul (isto é, Argentina, Brasil, Paraguai, Uruguai e Venezuela). Além disso, consideramos qualquer tipo de publicação publicada antes de 2020. Para fins de replicação (Aguinis, Ramani \& Alabduljader, 2017), nossa primeira expressão de busca é: TITLE-ABS-KEY ( "urban brand*" 
OR "urban mark*" OR "market* place\$" AND "Argentina" OR "Brazil" OR "Paraguay" OR "Uruguay" OR "Venezuela" ) AND PUBYEAR < 2020. A saber, 55 documentos resultaram desta expressão de busca. Ao ler o resumo desses documentos, removemos 47 documentos, pois não estão relacionados à imagem urbana, à marca urbana, ou aos países do Mercosul. Assim, nossa amostra final contém apenas 8 documentos que restaram do processo de limpeza.

Depois, conduzimos uma segunda busca na Scopus para abranger o termo marca da cidade: TITLE-ABS-KEY ("city brand*" AND "Argentina" OR "Brazil" OR "Paraguay" OR "Uruguay" OR "Venezuela") AND PUBYEAR < 2020. Três documentos foram obtidos desta expressão de busca, porém apenas dois artigos foram incluídos na análise (Zucco et al., 2017; Maielle \& Pasquinelli, 2015), e um artigo já incluído na primeira busca (Dinardi, 2017).

De acordo com Cooper (2017), muitas vezes, há mais de dois objetivos específicos nas sínteses de pesquisa. Neste estudo, há três objetivos específicos relacionados à imagem urbana na marca urbana e a marca da cidade como ferramenta de governança urbana dentro do contexto do Mercosul, dos quais foram considerados na seção de resultados e discussão: primeiro, as contribuições teóricas, idéias centrais e conclusões desses documentos; segundo, a distinção entre a ontologia da imagem urbana e a deontologia na região do Mercosul; e terceiro, os desafios na região do Mercosul.

\section{Resultados e discussão}

A tabela um apresenta uma lista das dez publicações selecionadas na síntese de pesquisa. Cinco lidam com a realidade urbana na Argentina (Carré \& Fernández, 2013; Dinardi, 2017; Lederman, 2015; Nunez \& Barelli, 2013; Roldán, 2013), quatro na realidade do Brasil (Scholvin \& Westhuizen, 2019; Yigitcanlar et al., 2018; Zucco et al., 2017; Maielle \& Pasquinelli, 2015), e um no contexto da Venezuela (Arroyo \& Montero, 2000). Não foram encontrados estudos sobre a imagem e a marca urbana do Paraguai e do Uruguai na amostra selecionada. 


\section{Tabela 1}

\section{Relação de Documentos da Amostra da Síntese de Pesquisa}

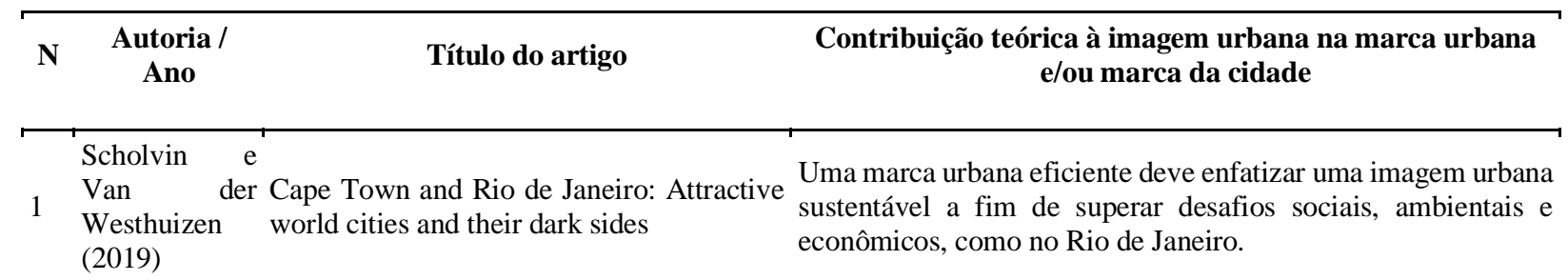

As marcas das cidades poderiam ser associadas à economia

Yigitcanlar et Towards smart Florianópolis: What does it urbana para desenvolver novas oportunidades econômicas.

Yigitcanlar et take to transform a tourist island into an Assim, a imagem urbana poderia ser uma ferramenta para
al. (2018) al. (2018) innovation capital? promover e induzir o desenvolvimento urbano, como em Florianópolis.

3 Dinardi Cities for sale: Contesting city branding and

Em Buenos Aires, as marcas institucionalizadas e reais da (2017) cultural policies in Buenos Aires cidade têm sido contrastantes. Assim, é necessário convergência entre stakeholders urbanos para fortalecer a marca da cidade.

Attributes of the Blumenau (Brazil) brand

4 Zucco et al. from the residents' perspective, and its (2017) influence on the decision to stay in the destination

A intenção de permanecer na cidade de Blumenau está positivamente relacionada à avaliação dos habitantes da cidade sobre os atributos da cidade e a marca da cidade.

Maiello e Destruction or construction? A (counter)

É possível a existência de uma marca oficial da cidade (hegemônica) e de uma marca contra-cidade (contra5 Pasquinelli branding analysis of sport mega-events in (2015) Rio de Janeiro FIFA 2014 e as Olimpíadas 2016.

6 Lederman $\begin{array}{ll}\text { Urban fads and consensual fictions: } \\ \text { Creative, sustainable, and competitive city }\end{array}$ A marca urbana pode ser útil à gestão urbana em termos de orientação de mercado e de valor, a fim de promover um desenvolvimento urbano mais justo, por exemplo, a marca criativa e sustentável em Buenos Aires.

$\begin{array}{ll}\text { Carré } & \mathrm{e} \\ \text { Fernández the green belt? Analysis of urban brand }\end{array}$ (2013) that never existed

Projetos urbanos e infra-estrutura poderiam ser parte essencial da marca urbana, por exemplo, o cinturão verde em Buenos Aires.

Fatores culturais influenciam como a marca urbana é constituída, que pode ser positiva, negativa e assim por diante.

$8 \begin{aligned} & \text { Núñez e Urban marks and social senses at issue. San } \\ & \text { Barelli (2013) Carlos de Bariloche, Argentina 1966 - } 1983\end{aligned}$ Stakeholders urbanos poderiam incentivar e desenvolver comportamentos desejados nas cidades, por exemplo, a cordialidade e atitudes éticas.

9 Roldán (2013) Inventaries of desire municipal census of

Dados coletados de censos poderiam ser utilizados pela governança urbana para formular uma marca urbana mais eficiente.

Arroyo e To build the city: A paradigm of urban A imagem urbana poderia ser uma ferramenta para atrair e

10 Montero management. The proposal of a method to

(2000) make urban plans viable sustentáveis e competitivas.

Fonte:Elaboração Própria.

Nota: $N$ = Número do artigo. Todos os documentos são artigos publicados em periódicos indexados à base de dados Scopus. 
O subtópico seguinte discute contribuições teóricas sobre a imagem urbana nos países do Mercosul, levando em conta os trabalhos selecionados na síntese de pesquisa. Depois disso, discutimos o construto de imagem urbana de acordo com os trabalhos selecionados, bem como os desafios relativos à imagem urbana nas cidades dos países do Mercosul.

\subsection{Sintese das contribuições teóricas sobre a imagem urbana no contexto do Mercosul}

Em prol da melhoria da imagem urbana, uma agenda inclusiva que propõe oportunidades socioeconômicas, sustentabilidade e inteligência urbana é crucial para as marcas urbanas na governança urbana, que consequentemente promove o desenvolvimento urbano sustentável. Scholvin e Van Der Westhuizen (2019) defendem que a imagem das cidades seja justa e realista, pois a atratividade das cidades não fosse baseada apenas pelas imagens retratadas nos megaeventos (como Copa do Mundo, Carnaval, e etc...), mas nos próprios ambientes em que as cidades se encontram. Em outras palavras, uma marca urbana eficiente deve enfatizar uma imagem sustentável da cidade em todas as dimensões da sustentabilidade (i.e. social, econômica e ambiental), pois uma imagem positiva está relacionada a um bom lugar para se viver e trabalhar, no qual todos os habitantes da cidade possuem as mesmas oportunidades e condições básicas de bem-estar. Quanto à infraestrutura urbana, Carré e Fernández (2013) demonstraram que alguns projetos urbanos de infra-estrutura urbana podem representar a cidade e ser parte essencial de sua marca urbana, e.g. en Buenos Aires, el cinturón ecológico (i.e. o cinturão ecológico ou cinturão verde) é considerado um marco territorial de sua marca.

A governança urbana deve considerar a economia urbana, o planejamento urbano, a infra-estrutura urbana, a cultura e o capital social como partes essenciais na marca urbana. De acordo com Yigitcanlar et al. (2018), a marca da cidade precisa estar associada à economia urbana para que novas oportunidades econômicas surjam. Por exemplo, a cidade de Florianópolis, Brasil, mudou sua marca de uma mera abordagem turística para uma perspectiva urbana de inteligência (no sentido de Cidade Inteligente ou Smart City) e inovação, a fim de atrair indústrias e capital social; esta última se baseia em uma economia do conhecimento e não em uma economia baseada em recursos. Também, Núñez e Barelli (2013) revelaram que fatores culturais influenciam a constituição da marca urbana, que pode ser positiva, negativa e dentre outras, e.g. como experiências anteriores de residentes com a imigrantes e casos de xenofobia podem fazer uma imagem negativa da cidade de San Carlos de Bariloche. 
Entretanto, às vezes a marca urbana pode ser uma ferramenta de marketing político e pode ter um aspecto negativo de "mercantilização" da cultura urbana; no entanto, tópicos institucionais e legais devem ser levados em consideração ao fazer e/ou gerenciar a marca urbana de forma apropriada, a fim de legitimar as políticas urbanas e promover competitividade justa na cidade. Dinardi (2017, p. 3, tradução nossa) afirmou que, por exemplo, em Buenos Aires, Argentina, "enquanto a criação da marca da cidade foi institucionalizada e suas características formais e uso são regulamentadas, marca urbana não combina com suas normas institucionalizadas na prática". De forma parecida, Maiello e Pasquinelli (2015) encontraram duas marcas de cidade contrastantes do Rio de Janeiro durante megaeventos, uma marca de cidade oficial positiva criada por governos e indústrias, e outra marca de cidade contra-oficial realista por movimentos sociais e stakeholders urbanos que reivindicam direitos e mudanças.

Assim, para lidar com esses problemas, Lederman (2015) defendeu uma perspectiva socioeconômica mais positiva, na qual a marca urbana poderia ser útil não apenas sob a orientação do mercado, mas também a orientação de valor da marca urbana poderia ser útil para proporcionar um desenvolvimento urbano mais justo, como no caso da marca criativa e sustentável em Buenos Aires, Argentina, de modo que, também, haja competição promovida no desenvolvimento urbano, Alinhado com Lederman (2015), Zucco et al. (2017) afirmou que, também, é útil que uma cidade possua uma avaliação socioeconômica positiva para seus cidadãos continuem desejando morar na cidade.

A fim de atrair mais investimentos, integrar objetivos industriais com a gestão urbana e aumentar a competitividade urbana, a gestão urbana pode integrar a marca urbana com planos diretores urbanos e outras ferramentas de planejamento urbano na governança urbana (Arroyo \& Montero, 2000). Também, Roldán (2013) afirmou que dados coletados de censos facilitam a governança urbana na formulação de uma marca urbana eficiente. Dados sociais, ambientais, econômicos e demográficos fornecem informações sobre os desejos dos stakeholders urbanos, e consequentemente, a marca urbana pode se tornar mais atraente e satisfatória.

Em suma, no contexto do Mercosul, a literatura tem revelado que a imagem urbana pode ser uma ferramenta de governança urbana para gestores urbanos e stakeholders urbanos melhorarem a imagem urbana, e assim, criar oportunidades socioeconômicas, promover cidades inteligentes e sustentáveis, e gerar convergência entre stakeholders urbanos. Além disso, stakeholders na governança urbana devem considerar unir questões econômicas urbanas, planejamento urbano, infra-estrutura urbana, questões culturais e capital social com a gestão de marcas urbanas, a fim de melhorar a imagem urbana e, assim, promover um desenvolvimento 
urbano desejável. Estes resultados encontrados na síntese de pesquisa estão alinhados com os trabalhos de Lucarelli e Berg (2011), Rehan (2014), Zucco et al. (2017), e Beck e Storopoli (2021) sobre a importância da imagem urbana na governança urbana em termos de atratividade urbana, satisfação e tomada de decisões de stakeholders e dos gestores urbanos.

\subsection{Imagem urbana no Mercosul, como ela é e como ela deveria ser}

A imagem urbana poderia ser explorada na governança urbana para fomentar o desenvolvimento urbano e para atender às necessidades dos stakeholders urbanos. Scholvin e Van Der Westhuizen (2019), Lederman (2015), e Arroyo e Montero (2000) entenderam a imagem urbana como uma forma utilizada pelas cidades para atrair vários tipos de empresas, investimentos nacionais e internacionais, pessoas criativas e maior qualidade do capital social, e assim, promover um desenvolvimento urbano fundamentado nas ideias de cidade criativa, sustentável e competitiva. Uma imagem urbana positiva pressupõe que as cidades devem ser um espaço de competitividade e de consumo (Arroyo \& Montero, 2000), e uma imagem urbana positiva desempenha um papel fundamental no desejo dos munícipes continuarem vivendo na cidade (Zucco et al., 2017). No mesmo sentido, Yigitcanlar et al. (2018) interpretaram a imagem urbana como uma ferramenta para promover e induzir o desenvolvimento urbano, a qual muda a percepção da cidade pelos stakeholders urbanos, conectada com uma agenda econômica desejada pela governança urbana, e então, diversificando as atividades econômicas urbanas e alcançando um desempenho econômico sustentável e tornando mais independente o desempenho econômico das cidades.

Porém, é difícil haver convergência entre stakeholders urbanos. De acordo com Dinardi (2017, p. 11, tradução nossa), é difícil haver uma imagem urbana de comum entendimento de forma geral: "Diferentes entendimentos de cultura fazem que as cidades sejam imaginadas de inúmeras formas, e seus moradores dependerão de quem possui o poder para representar a imagem-dominante". Por exemplo, em Buenos Aires, Argentina, há diversas interpretações de imagem urbana, a qual depende do status socioeconômico, das raízes culturais, das crenças e do tipo de stakeholder urbano (e.g. turista, empresário, residente, dentre outros...).

Em concordância com Dinardi (2017), Maiello e Pasquinelli (2015) estudaram os casos da Copa do Mundo de 2014 e das Olimpíadas 2016, e encontraram duas interpretações diferentes da imagem da cidade do Rio de Janeiro - a marca oficial e a marca de contra oficial: (1) por um lado, a marca oficial era administrada pelo governo e pela indústria, na qual a imagem da cidade era muito positiva e bonita; (2) por outro lado, a marca de contra oficial era 
advinda dos movimentos sociais reivindicando direitos e melhores condições de vida, na qual a imagem da cidade era real e contra-hegemônica. Assim, o resultado de múltiplas interpretações das imagens urbanas é a competição de interesses diferentes, o que requer mais esforço para convergir sobre qual marca urbana deve ser escolhida: "Diferentes interpretações da cultura e visões urbanas conflituosas impactam como as políticas de inclusão social serão administradas" (Dinardi, 2017, p. 13, tradução nossa).

A governança urbana deve considerar aspectos tangíveis e intangíveis na gestão da imagem urbana. Por um lado, os aspectos tangíveis e físicos, bem como a infra-estrutura urbana, são importantes para a imagem urbana, Carré e Fernández (2013) afirmam que a imagem urbana pode ser parcialmente derivada de projetos de infraestrutura urbana. Por outro lado, os aspectos intangíveis das cidades também são importantes, tanto que Núñez e Barelli (2013) afirmaram que a imagem das cidades não é criada apenas por aspectos tangíveis e físicos, mas também por aspectos intangíveis, psicológicos e comportamentais. Por isso, Roldán (2013) afirmou que a imagem urbana deve, também, refletir questões sociais, ambientais, econômicas e demográficas a fim de satisfazer e atrair mais residentes, turistas, empresas e indústrias. Ou seja, as características das cidades são importantes para a construção e gestão da imagem urbana.

Em síntese, embora uma imagem urbana positiva possa promover o desenvolvimento urbano e aumentar o desempenho da governança urbana ao satisfazer os stakeholders urbanos, é muito difícil convergir sobre o que é imagem urbana e como ela deveria ser. Haja visto que há inúmeros stakeholders na governança urbana, a própria cidade e a imagem urbana podem ter significados, sentimentos e propósitos diferentes para múltiplos stakeholders urbanos. No contexto do Mercosul, as marcas institucionais das cidades não têm sido concretas para muitos stakeholders urbanos, assim como a existência de marcas oficiais e contra oficiais das cidades tem comprometido a legitimidade da marca da cidade e da imagem urbana (e.g. Dinardi, 2017; Maiello \& Pasquinelli, 2015). Por isso, aspectos tangíveis e intangíveis na gestão da imagem urbana devem ser explorados e bem aproveitados pela governança urbana.

\subsection{Os desafios da imagem urbana no Mercosul}

Como localizadas em países em desenvolvimento, as cidades do Mercosul têm enormes desafios de desigualdade sócio-econômica a serem enfrentados. Considerando o papel da marca urbana na governança e no desenvolvimento urbano, a imagem urbana deve ser bem administrada para atrair o público-alvo da cidade e satisfazer stakeholders urbanos. Por exemplo, o Rio de Janeiro tem que lidar com extrema desigualdade socioeconômica - em que 
há pessoas muito ricas e outras muito pobres - e falta de oportunidades para os cidadãos mais vulneráveis (Scholvin \& Van Der Westhuizen, 2019).

Desta forma, a construção de uma imagem urbana eficiente poderia ajudar a governança urbana a superar desafios urbanos socioeconômicos, ambientais e éticos (Yigitcanlar et al., 2018). Uma imagem urbana eficiente deve considerar (Yigitcanlar et al., 2018; Núñez \& Barelli, 2013; Roldán, 2013): (1) como os processos de urbanização têm sido desenvolvidos ao longo do tempo (e.g. aumento populacional e gentrificação);(2) ocupação urbana legal ou ilegal (e.g. comunidades carentes e favelas); (3) mobilidade sustentável; (4) questões ambientais e de segurança; (5) questões éticas, e.g. desvio de conduta de gestores públicos; (6) como a imagem urbana tem sido reconhecida, percebida e vista por outros, seja em nível local, nacional ou internacional, indepedente se estes outros são ou não stakeholders na governança urbana; (7) uso ético de dados na gestão de marcas urbanas; e (8) incentivo a comportamentos socialmente desejados das comunidades locais, e.g. recebendo cordialmente novos migrantes e dentre outras atitudes éticas.

Há muita complexidade e incerteza nas questões socioeconômicas urbanas e nos processos urbanos, seja por causa dos múltiplos stakeholders ou dos inúmeros temas e pautas urbanas. A imagem urbana real e a desejada variará de acordo com o tipo de stakeholder urbano. Por esse motivo, a governança urbana deve considerar: (1) responder de forma equilibrada às pressões dos segmentos de mercado e não-mercados é outro desafio da governança urbana, pois deve-se priorizar simultaneamente as necessidades dos cidadãos, das empresas e dos turistas (Lederman, 2015); (2) como os processos urbanos são difíceis de interpretar pois são incertos e complexos, a marca urbana deve ser elaborada com estratégia e cautela (Arroyo \& Montero, 2000); (3) criar uma imagem urbana inclusiva por meio do engajamento de stakeholders e consenso (Dinardi, 2017); e (4) gerenciar uma imagem urbana lucrativa que não perca os aspectos culturais e sociais das cidades, por exemplo, evitando a mera "consumerização" da cultura por parte dos turistas (Dinardi, 2017).

Também, há um conflito entre o que uma imagem urbana visa demonstrar e o que ela realmente é. Assim, demonstrar uma imagem urbana realmente positiva de uma cidade sustentável, democrática e próspera é um dos maiores desafios nas cidades do Mercosul. Os trabalhos de Carré e Fernández (2013) e Maiello e Pasquinelli (2015) dão exemplos: 
- Carré e Fernández (2013) relataram que el cinturón ecológico (i.e. o cinturão ecológico ou cinturão verde) em Buenos Aires, criado sob os preceitos da escola modernista de urbanismo, mostraram que, apesar de algumas áreas verdes da cidade foram preservadas, el cinturón ecológico não é sustentável. Pois, isso incentiva o uso de veículos privados por partes dos cidadãos e cria uma imagem urbana imaginária de que as áreas verdes dentro dos distritos urbanos não são mais necessárias pois já existem áreas verdes preservadas ao redor da cidade;

- Maiello e Pasquinelli (2015) revelaram que em megaeventos ocorridos no Rio de Janeiro, a marca oficial da cidade criada pela administração urbana, governos e principais atores industriais tentam mostrar uma imagem urbana positiva, ocultando questões socioeconômicas e ambientais defendidos por stakeholders (e.g. cidadãos e pequenas empresas). Apesar da marca oficial da cidade ser chamada de "oficial", ela não reflete as condições reais da cidade, portanto, sua legitimidade é questionável.

Em suma, os desafios da governança urbana sobre a imagem urbana nos países do Mercosul estão especialmente relacionados às desigualdades socioeconômicas, ambientais e questões éticas. Em geral, stakeholders urbanos na governança urbana devem procurar melhorar a imagem urbana, fomentar um desenvolvimento urbano próspero ao gerenciar a imagem urbana por meio do consenso entre todos stakeholders urbanos, existir conexão sobre a imagem urbana real para a desejada, e incentivar os habitantes da cidade a terem comportamentos eticamente apropriados para que a imagem urbana seja mais positiva.

\section{Considerações finais}

Atingimos o objetivo da pesquisa analisando e sintetizando a estrutura de conhecimento sobre a imagem urbana e da cidade como uma ferramenta para a governança urbana dentro do contexto do Mercosul. Para isso, nossa síntese de pesquisa concentrou-se nas contribuições teóricas, na compreensão da imagem urbana ontológica e deontológica, e nos desafios regionais nas cidades do Mercosul.

Nossos resultados revelam que: (1) as contribuições teóricas dos trabalhos contidos na síntese de pesquisa estão alinhadas com a pesquisa seminal em marcas urbanas, e que as pesquisas sobre a imagem urbana no contexto do Mercosul mostram que a criação de oportunidades socioeconômicas, inclusão, sustentabilidade, convergência e satisfação dos stakeholders, inteligência urbana (cidades inteligentes) e atratividade da cidade são partes 
essenciais da imagem urbana como uma ferramenta de governança urbana para o desenvolvimento urbano sustentável; (2) é necessário consenso sobre a imagem urbana deontológica e ontológica entre stakeholders na governança urbana para garantir integração e legitimidade da imagem urbana, a qual seria comumente aceita por todos stakeholders urbanos, seja quanto aos aspectos tangíveis (e.g. infraestrutura, desenho urbano, dentre outros) ou aspectos intangíveis das cidades (e.g. sociais, psicológicos, comportamentais, culturais, dentre outros); e (3) os desafios da governança urbana sobre a imagem urbana no contexto do Mercosul são principalmente aqueles relacionados às desigualdades socioeconômicas, preocupações ambientais e questões éticas.

A originalidade deste trabalho é a aplicação de uma síntese de pesquisa para analisar a estrutura de conhecimento relacionada à imagem das cidades como uma ferramenta de governança urbana dentro do contexto do Mercosul. Nossas contribuições teóricas apenas reforçam as discussões da literatura seminal de marca urbana no âmbito das pesquisas sobre a imagem urbana no contexto do Mercosul, mas também sobre este trabalho é original ao apresentar desafios regionais e a existência de diferentes perspectivas deontológicas e ontológicas de inúmeros stakeholders na governança urbana das cidades do Mercosul.

Profissionais, tais como urbanistas, gestores urbanos e formuladores de políticas dos mais variados assuntos urbanos, podem se beneficiar dos resultados e discussões desenvolvidas neste estudo. Tais profissionais devem considerar as expectativas e necessidades dos stakeholders urbanos na gestão da imagem da cidade a fim de fortalecer as instituições democráticas, criar consenso entre stakeholders urbanos, promover o desenvolvimento urbano sustentável e superar os desafios regionais.

As contribuições sociais deste estudo consistem em esclarecer como uma imagem urbana positiva pode melhorar o relacionamento entre stakeholders urbanos na governança urbana das cidades dos países do Mercosul e em esclarecer como uma gestão orientada aos stakeholders é fundamental para assegurar a convergência entre stakeholders urbanos sobre como a imagem urbana é e como a imagem urbana deve ser nas cidades do Mercosul. Assim, comunidades regionais e locais estarão mais satisfeitas e a governança urbana será mais democrática com uma abordagem bottom-up (decisões tomadas de baixo para cima, com maior participação, empoderamento e inovação entre os stakeholders).

Nossa agenda de estudos futuros sugere a necessidade de: (1) avaliar a marca da cidade e as estratégias de imagem urbana sobre sua eficácia nos países emergentes, como no contexto do Mercosul (Florek et al., 2021); (2) explorar como processos urbanos e produtos urbanos 
podem ser usados para melhorar a imagem urbana, especialmente em cidades inteligentes (Beck \& Conti, 2021; Yigitcanlar et al., 2018); (3) explorar os construtos de stakeholders, de saliência de stakeholders (stakeholder salience) e criação de valor (value creation) em marcas urbanas, marca da cidade, imagem urbana, e gestão da imagem da cidade (Beck \& Storopoli, 2021) e na marca de país em termos de imagem e reputação (Mariutti \& Giraldi, 2020); (4) compreender qual é a possível relação entre a percepção da marca do país e a percepção da marca da cidade, e como a orientação aos stakeholders modera tal relação na governança urbana; e (5) explorar o papel de uma gestão orientada aos stakeholders e da visão baseada em recursos (resourcebased view) na governança urbana em prol do patrimônio da marca da cidade e da imagem urbana (Górska-Warsewicz, 2020; Hanna et al., 2021; Beck \& Storopoli, 2021; Freeman, Dmytriyev, \& Phillips, 2021).

A principal limitação deste estudo é que extraímos dados somente do banco de dados Scopus, que é considerado o banco de dados mais abrangente em estudos urbanos e ciências sociais. Assim, pesquisas posteriores devem considerar outras bases de dados, como o Web of Science. Como nossa síntese de pesquisa tem um procedimento sistemático de coleta de dados, alguns estudos podem estar fora da amostra porque a base de dados retorna apenas documentos com os termos que usamos nas expressões de busca nos títulos, resumos e palavras-chave.

\section{Referências}

Aguinis, H., Ramani, R. S., \& Alabduljader, N. (2017). What You See Is What You Get? Enhancing Methodological Transparency in Management Research. Academy of Management Annals, 12(1), 83-110. https://doi.org/10.5465/annals.2016.0011

Arroyo, M. F., \& Montero, N. A. (2000). To build the city: A paradigm of urban management. The proposal of a method to make urban plans viable. Revista Venezolana de Gerencia, 5(10), 91-109.

Ashworth, G., \& Kavaratzis, M. (2009). Beyond the logo: Brand management for cities. Journal of Brand Management, 16, 520-531. https://doi.org/10.1057/palgrave.bm.2550133

Avraham, E., \& Ketter, E. (2008). Media Strategies for Marketing Places in Crisis: Improving the image of Cities, Countries and Tourist destinations. Elsevier: Amsterdam.

Beck, D., \& Storopoli, J. (2021). Cities through the lens of Stakeholder Theory: A literature review. Cities, 118, 103377. https://doi.org/10.1016/j.cities.2021.103377

Beck, D. F. \& Conti, D. M. (2021). The Role of Urban Innovativeness, Smart Governance, and Smart Development in the Urban Smartness. Humanidades \& Inovação, 8(49), 141151. Disponível em: https://revista.unitins.br/index.php/humanidadeseinovacao/article/view/5134 
Braun, E., Kavaratzis, M., \& Zenker, S. (2013). My city - my brand: The different roles of residents in place branding. Journal of Place Management and Development, 6(1), 18-21. https://doi.org/10.1108/17538331311306087

Campelo, A. (2015). Rethinking Sense of Place: Sense of One and Sense of Many. In: Kavaratzis, M., Warnaby, G., \& Ashworth, G. J. (eds). Rethinking Place Branding: Comprehensive brand development for cities and regions (pp. 51-60). Cham: Springer.

Cañizares, S. M. S., Tabales, J. M. N., \& Garcia, F. J. F. (2014). Local residents' attitudes towards the impact of tourism development in Cape Verde. Tourism \& Management Studies, 10(1), 87-97.

Carré, M., \& Fernández, L. (2013). Is the green belt? Analysis of urban brand that never existed. Eure, 39(117), 49-68. https://doi.org/10.4067/S0250-71612013000200003

Cooper, H. (2017). Research synthesis and meta-analysis (5th ed.). Thousand Oaks: SAGE Publications, Inc.

Dinardi, C. (2017). Cities for sale: Contesting city branding and cultural policies in Buenos Aires. Urban Studies, 54(1), 85-101. https://doi.org/10.1177/0042098015604079

Evans, G. (2015). Rethinking Place Branding and Place Making Through Creative and Cultural Quarters. In: Kavaratzis, M., Warnaby, G., \& Ashworth, G. J. (eds). Rethinking Place Branding: Comprehensive brand development for cities and regions (pp. 135-158). Cham: Springer.

Florek, M., Hereźniak, M., \& Augustyn, A. (2021). Measuring the effectiveness of city brand strategy. In search for a universal evaluative framework. Cities, 110, 103079. https://doi.org/10.1016/j.cities.2020.103079

Florek, M., Insch, A., \& Gnoth, J. (2006). City council websites as a means of place brand identity communication. Place Branding, 2(4), 276-296.

https://doi.org/10.1057/palgrave.pb.6000036

Florek, M., \& Kavaratzis, M. (2014). From brand equity to place brand equity and from there to the placebrand. Place Branding and Public Diplomacy, 10(2), 103-107. https://doi.org/10.1057/pb.2014.9

Fouts, J. S. (2010). Social Media and Immersive Worlds: Why International Place Branding Doesn't Get Weekends Off. In: Go, F. M., \& Govers, R. (eds.). International Place Branding Yearbook 2010: Place Branding in the New Age of Innovation (pp. 113-119) New York: Palgrave Macmillan.

Freeman, R. E., Dmytriyev, S. D., \& Phillips, R. A. (2021). Stakeholder theory and the resource-based view of the firm. Journal of Management, 47(7), 1757-1770. https://doi.org/10.1177/0149206321993576.

Górska-Warsewicz, H. (2020). Factors Determining City Brand Equity-A Systematic Literature Review. Sustainability, 12(19), 7858. https://doi.org/10.3390/su12197858 
Govers, R., \& Go, F. M. (2010). The E-branding of Places. In: Go, F. M., \& Govers, R. (eds.). International Place Branding Yearbook 2010: Place Branding in the New Age of Innovation (pp. 121-133) New York: Palgrave Macmillan.

Green, A., Grace, D., \& Perkins, H. (2016). City branding research and practice: An integrative review. Journal of Brand Management, 23(3), 252-272. https://doi.org/10.1057/bm.2016.8

Halemane, M., Janszen, F., \& Go, F. M. (2010). Orchestrating the Innovation Process of Place Branding. In: Go, F. M., \& Govers, R. (eds.). International Place Branding Yearbook 2010: Place Branding in the New Age of Innovation (pp. 172-183) New York: Palgrave Macmillan.

Hanna, S. A., \& Rowley, J. (2015). Rethinking Strategic Place Branding in the Digital Age. In: Kavaratzis, M., Warnaby, G., \& Ashworth, G. J. (eds). Rethinking Place Branding: Comprehensive brand development for cities and regions (pp. 85-100). Cham: Springer.

Hanna, S., Rowley, J., \& Keegan, B. (2021). Place and Destination Branding: A Review and Conceptual Mapping of the Domain. European Management Review, 18(2), 105-117. https://doi.org/10.1111/emre.12433

Hankinson, G. (2015). Rethinking the Place Branding Construct. In: Kavaratzis, M., Warnaby, G., \& Ashworth, G. J. (eds). Rethinking Place Branding: Comprehensive brand development for cities and regions (pp. 13-32). Cham: Springer.

Kavaratzis, M., \& Ashworth, G. J. (2005). City Branding: An effective assertion of identity or a transitory marketing trick? Journal of Economic and Social Geography, 96(5), 506-514. https://doi.org/10.1111/j.1467-9663.2005.00482.x

Kavaratzis, M. (2005). Place Branding: A Review of Trends and Conceptual Models. The Marketing Review, 5(4), 329-342. https://doi.org/10.1362/146934705775186854

Kavaratzis, M., \& Hatch, M. J. (2013). The dynamics of place brands: An identity-based approach to place branding theory. Marketing Theory, 13(1), 69-86. https://doi.org/10.1177/1470593112467268

Kerr, G., \& Oliver, J. (2015). Rethinking Place Identities. In: Kavaratzis, M., Warnaby, G., \& Ashworth, G. J. (eds). Rethinking Place Branding: Comprehensive brand development for cities and regions (pp. 61-72). Cham: Springer.

Kotler, P., Haider, D. H., \& Rein, I. (1993). Marketing places: attracting investment, industry, and tourism to cities, states, and nations. New York: The Free Press.

Lederman, J. (2015). Urban fads and consensual fictions: Creative, sustainable, and competitive city policies in Buenos Aires. City and Community, 14(1), 47-67. https://doi.org/10.1111/cico.12095 
Lucarelli, A., \& Berg, P. O. (2011). City branding: a state-of-the-art review of the research domain. Journal of place management and development, 4(1), 9-27. https://doi.org/10.1108/17538331111117133

Lucarelli, A., \& Giovanardi, M. (2016). The political nature of brand governance: a discourse analysis approach to a regional brand building process. Journal of Public Affairs, 16(1), 1627. https://doi.org/10.1002/pa.1557

Maiello, A., \& Pasquinelli, C. (2015). Destruction or construction? A (counter) branding analysis of sport mega-events in Rio de Janeiro. Cities, 48, 116-124. https://doi.org/10.1016/j.cities.2015.06.011

Mariutti, F.G., \& Tench, R. (2016). How does Brazil measure up? Comparing rankings through the lenses of nation brand indexes. Place Branding and Public Diplomacy, 12(1), 17-31. https://doi.org/10.1057/pb.2015.19

Mariutti, F. G. (2017). The placement of country reputation towards place management. Journal of Place Management and Development, 10(3), 240-253. https://doi.org/10.1108/JPMD-10-2016-0067

Mariutti, F. G., \& Giraldi, J. M. E. (2019). Country brand personality of Brazil: a hindsight of Aaker's theory. Place Branding and Public Diplomacy, 16, 1-14. https://doi.org/10.1057/s41254-019-00153-3

Mariutti, F. G., \& Giraldi, J. M. E. (2020). Country brand equity: The role of image and reputation. Brazilian Administration Review, 17(3), e180128. https://doi.org/10.1590/18077692 bar2020180128

Morgan, N., \& Pritchard, A. (2001). Advertising in Tourism \& Leisure. Woburn: ButterworthHeinemann.

Núñez, P. G., \& Barelli, A. I. (2013). Urban marks and social senses at issue. San Carlos de Bariloche, Argentina 1966 - 1983. HiSTOReLo, 5(10), 164-196.

Oliveira, E. (2015). Place branding as a strategic spatial planning instrument. Place Branding and Public Diplomacy, 11(1), 18-33. https://doi.org/10.1057/pb.2014.12

Oguztimur, S., \& Akturan, U. (2016). Synthesis of city branding literature (1988-2014) as a research domain. International Journal of Tourism Research, 18(4), 357-372. https://doi.org/10.1002/jtr.2054

Pedeliento, G., \& Kavaratzis, M. (2019). Bridging the gap between culture, identity, and image: A structurationist conceptualization of place brands and place branding. Journal of Product \& Brand Management, 28 (30), 348-363. https://doi.org/10.1108/JPBM-01-20181735

Pierre, J. (2011). The Politics of Urban Governance. Hampshire: Palgrave Macmillan.

Rehan, R. M. (2014). Urban branding as an effective sustainability tool in urban development. HBCR Journal, 10(2), 222-230. https://doi.org/10.1016/j.hbrcj.2013.11.007 
Roldán, D. P. (2013). Inventaries of desire municipal census of Rosario, Argentina (18891910). História (São Paulo), 32(1), 327-353. https://doi.org/10.1590/s010190742013000100018

Scholvin, S., \& van der Westhuizen, J. (2019). Cape Town and Rio de Janeiro: Attractive world cities and their dark sides. Geographische Rundschau, 71(11), 44-49.

Skinner, H. (2008). The emergence and development of place marketing's confused identity. Journal of Marketing Management, 24(9-10), 915-928. https://doi.org/10.1362/026725708X381966

Yigitcanlar, T., Sabatini-Marques, J., Lorenzi, C., Bernardinetti, N., Schreiner, T., Fachinelli, A., \& Wittmann, T. (2018). Towards smart florianópolis: What does it take to transform a tourist island into an innovation capital? Energies, 11(12), art. No. 3265. https://doi.org/10.3390/en11123265

Zenker, S., Braun, E., \& Petersen, S. (2017). Branding the destination versus the place: The effects of brand complexity and identification for residents and visitors. Tourism Management, 58, 15-27. https://doi.org/10.1016/j.tourman.2016.10.008

Zucco, F. D., Reis, C., Anjos, S. J. G., Effting, S. J., \& Pereira, M. L. (2017). Attributes of the Blumenau (Brazil) brand from the residents' perspective, and its influence on the decision to stay in the destination. International Journal of Tourism Cities, 3(1), 43-55.

https://doi.org/10.1108/IJTC-10-2016-0044 